\title{
Evaluating water quality regulation as a driver of farmer behavior: a social- ecological systems approach
}

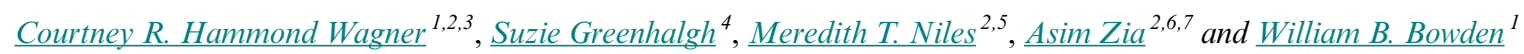

\begin{abstract}
Water quality policy for agricultural lands seeks to improve water quality by changing farmer behavior. We investigate farmer behavior in three water quality regimes that differ by rule structure to examine the fit and interplay of each policy within its social-ecological context, important aspects for improving water quality. Vermont, USA's practice-based policy requires the adoption of specific practices, whereas New Zealand's Lake Taupo and Lake Rotorua performance-based policies require farmers to meet a numeric limit for nutrient loss on their farm. Across the three regions we interviewed 38 farmers to elicit mental models of nutrient management changes. We utilized the social-ecological systems (SES) framework to guide mental model elicitation, drawing on farmers' perceptions of the SES to identify salient aspects for behavior. Mental models were grouped by region and analyzed using network analysis. Farmers in all regions self-report high levels of behavior change and cite the policies as key drivers of behavior. This suggests that each policy fits in that it is achieving desired behavior change. However, different behavioral patterns emerged across the regions that we hypothesize have implications for biophysical fit: structural changes dominate in Vermont (e.g., buffers) and system changes in Taupo (e.g., switch from dairy support to beef cattle). The interplay of the policy in each setting, such as with incentive programs in Vermont and a market for nitrogen in Taupo, contributed to the different behavioral patterns. Additionally, access to capital in some form is required for farmers to achieve changes associated with higher biophysical fit. The social fit of the policies also varied, evidenced by dramatic upheaval in Taupo to mostly neutral perceptions of the policy in Vermont. We conclude that regions considering a shift to water quality rules for farms should carefully consider behavioral dynamics in policy design to achieve water quality goals.
\end{abstract}

Key Words: environmental regulation; farmer decision making; mental models; social-ecological systems; water quality

\section{INTRODUCTION}

Water quality policy targeting agricultural nonpoint source(NPS) pollution strives to improve water quality by changing farmer behavior across the landscape. Despite the pervasive impact of agricultural NPS pollution to freshwater systems, little is known about the social, economic, and political dynamics that contribute to the persistence of the problem, including the role of mandatory NPS pollution policy in changing farmer behavior (Carpenter et al. 1998, McDowell et al. 2016, Rissman and Carpenter 2015). The types of land management changes farmers make on their land and the drivers that influence these behaviors are signals of whether water quality will improve and if behavior is changing as intended. The mental models farmers hold with respect to the motives for their nutrient management behavior can help identify underlying mechanisms driving behavior (Jones et al. 2011, Saldaña 2015). Understanding farmers' mental models can in turn shed light on the fit of a water quality policy within the broader watershed context, and social and ecological outcomes.

For water quality policy to achieve the desired outcome it must fit well within the social-ecological context and have good interplay with the pre-existing institutions that structure interaction and behavior in a given setting (Goodin 1998, Young et al. 2008). Institutions refer to the rules, strategies, or norms that constrain human interaction and behavior (North 1990, Ostrom 2005). Policy or institutional fit refers to the ways in which institutions fit "ecosystem dynamics, our priorities concerning these, and what rules "fit" these issues," but importantly, also the way in which an institution shapes human action (Vatn and Vedeld 2012). As Vatn and Vedeld (2012) describe, "No regime can fit a resource...if the regime is unable to create the actions wanted or needed."

Because of challenges in measuring and monitoring agricultural NPS pollution (Meals et al. 2010), it is difficult to assess the ecological fit of a water quality policy through water quality trends. Instead, we can identify links between the policy and actions of interest that drive NPS pollution trends, i.e., farmer behavior change, to assess the fit of the policy with the biophysical system. In particular, we focus on the type of behavior changes being made on the land to assess biophysical fit because not all nutrient management changes will have the same ecological impact long term. We can assume that a reversible management change in the amount of fertilizer applied will have a lower effectiveness on improving water quality in the long term than a farm system transition from a high nutrient loss system, like a dairy farm, to a lower nutrient loss land use, like forestry.

Alongside the biophysical fit of the policy, we can look to farmer perceptions to examine the social fit of the policy, or "how well institutions match human expectations and local behavioral patterns" (DeCaro and Stokes 2013) to understand institutional acceptance of a policy. With the typically slow movement of nutrients in the landscape, it is difficult for farmers to see a causeand-effect relationship between behavior changes induced by a policy and water quality improvement. Therefore long-term buyin and acceptance of the policy as legitimate is critical (DeCaro

\footnotetext{
${ }^{1}$ Rubenstein School of the Environment and Natural Resources, University of Vermont, ${ }^{2}$ Gund Institute for Environment, University of Vermont, ${ }^{3}$ Water in the West, Woods Institute for the Environment, Stanford University, ${ }^{4}$ Manaaki Whenua Landcare Research, New Zealand, ${ }^{5}$ Department of Nutrition and Food Sciences \& Food Systems Program, University of Vermont, ${ }^{6}$ Department of Community Development and Applied Economics, University of Vermont, ${ }^{7}$ Department of Computer Science, University of Vermont
} 
and Stokes 2013). With farmer behavior and mental models we can assess qualitatively the social and biophysical fit of a water quality policy.

We investigate farmer behavior in three agricultural NPS pollution policies in Vermont, USA and Taupo and Rotorua, New Zealand (NZ), targeting the same biophysical challenge: the reduction of water quality due to runoff of nutrients from agricultural landscapes. In each policy, farmers have a set of "choice rules," which specify what a farmer "must, must not, or may do" (Ostrom 2005:200). These mandatory policies represent two different types of choice rules: practice-based and performance-based. Under Vermont's practice-based policy, farmers must implement a series of practices or structures to be in compliance (VAAFM 2018). In the NZ performance-based policies, farms must stay under a performance limit for modeled nutrient leaching, but they can choose any suite of strategies to achieve the standard (WRC 2011a, BOPRC 2016). The Taupo policy has been in operation since 2011, Vermont since 2016, and the Rotorua process is yet to be implemented and therefore represents a policy signal, i.e., requirements of policy are known but not yet enforced.

We present a novel methodology, integrating the social-ecological systems (SES) framework and mental models analysis, to address three key research questions: (1) What types of nutrient management behavior changes do farmers report making? (2) What do farmers perceive as the drivers of their nutrient management changes? And (3) what are the perceived individual and watershed outcomes of behavior changes and the NPS pollution policy? The aim of this analysis is to identify and assess the behavior changes induced by policies developed to improve water quality and the social and ecological factors driving behavior, both important components of policy fit and interplay (Young et al. 2008, Vatn and Vedeld 2012, DeCaro and Stokes 2013). We did not attempt to assess the effectiveness of policy to achieve water quality improvement because not enough time has passed to see marked improvements in water quality.

\section{Theoretical framework}

Ostrom's SES framework (2009) considers the way in which interactions between governance systems, users, resource systems, resource units, and system outcomes exist within broader social, economic, political, and ecological dynamics. Typically in applications of the SES framework researchers use a diversity of metrics (Cox 2014, McGinnis and Ostrom 2014, Leslie et al. 2015), but rarely include perspectives of individual actors. Here we draw on farmers' perceptions of dynamics in the SES, i.e., mental models, to identify the most salient aspects of the system to behavior as a basis for examining policy fit and interplay, given that the aim of agricultural NPS pollution policy is to improve water quality through changing farmer behavior. As Ekstrom and Young (2009) note, identifying institutional fit at the system-wide scale requires incorporating the "full suite of institutions relating directly or indirectly to a socioecological system." In our case studies, we look to farmers to identify the suite of institutions they perceive as causal drivers of their behavior.

Exploring farmer mental models within the context of a water quality policy can provide important insight into how farmers make decisions that ultimately impact water quality (Carley and Palmquist 1992). A mental modeling approach has been employed to understand a broad range of environmental behavior, including irrigator water-use decisions (Douglas et al. 2016), definitions of sustainable agriculture (Hoffman et al. 2014), weed management decisions (Jabbour et al. 2014), and climate change beliefs (Zia and Todd 2010). Furthermore, we group mental models by region into regional mental models to examine "collective knowledge and understanding of a particular domain held by a specific population of individuals" (Hoffman et al. 2014:13016).

\section{Study site descriptions}

Rotorua and Taupo, NZ and Vermont, USA have each implemented agricultural NPS pollution policy that regulates nutrient loss from farms. The three regions are agriculturally dominated landscapes that have seen recent agricultural intensification associated with decreases in water quality (Rutherford et al. 1989, Mcdowell et al. 2009, Quinn et al. 2009, Smeltzer et al. 2012, Smeltzer 2015; see Fig. 1). Note that in Figure 1 we show one watershed in Vermont, the Missisquoi watershed to represent land use in Vermont at a similar scale to Taupo and Rotorua, but the policy in Vermont is state-wide and therefore at a much larger scale. Table 1 gives a description of each of the three case study regions using the high-level SES categories.

\section{Taupo, $N Z$}

The Lake Taupo watershed, on NZ's North Island, is dominated by pastoral agriculture, with approximately 113 sheep and cattle farms and seven dairies, and has a spatial extent of $2865 \mathrm{~km}^{2}(\mathrm{~J}$. Palmer 2020, WRC, personal communication). Approximately $19 \%$ of the Taupo watershed is in pastoral agriculture, $23 \%$ is in forestry, $56 \%$ is indigenous vegetation or undeveloped land, and $2 \%$ is in developed land uses (Barnes and Young 2012). With declining water quality, the Waikato Regional Council proposed "Variation No. 5" of the Waikato Regional Plan in 2005 to clean up Lake Taupo (WRC 2011a). The policy, which became operational in 2011, is a performance-based cap-and-trade program for nitrogen. Under the policy, farm nitrogen leaching was capped at historical levels. Each farm was allocated a nitrogen discharge allowance based on their highest modeled annual nitrogen loss between 2001 and 2005 (WRC 2011a). A public fund managed by the Lake Taupo Protection Trust was established to permanently reduce nitrogen losses in the watershed by $20 \%$ and achieve the environmental goal of restoring the lake to 2001 water quality levels by 2080 . The NZD\$80 million endowment to the Trust was an equal contribution from local, regional, and national government (Kerr et al. 2015). Additionally, a nitrogen market was established to provide flexibility to farmers in how they met their regulated individual discharge allowance while also achieving the overall basin cap. Farms are monitored annually to ensure compliance with their nitrogen discharge allowance and pay an annual fee (WRC 2011b).

\section{Rotorua, NZ}

Lake Rotorua watershed is located about $80 \mathrm{~km}$ northeast of Lake Taupo and is also dominated by pastoral agriculture, but more concentrated: the watershed features 407 farms, including 107 dairies, and has a spatial extent of $500 \mathrm{~km}^{2}$ (The Rotorua Lakes Protection and Restoration Action Programme 2009; D. Smeaton 2020 , personal communication). Approximately $42 \%$ of the Lake Rotorua watershed is in pastoral agriculture, $18 \%$ is in forestry, $21 \%$ is indigenous vegetation, and $19 \%$ is in developed land uses 
Table 1. Social-ecological system description of the three case study regions.

\begin{tabular}{|c|c|c|c|}
\hline $\begin{array}{l}\text { Case study policy } \\
\text { regions }\end{array}$ & $\begin{array}{l}\text { Taupo, Waikato Region, New } \\
\text { Zealand }\end{array}$ & $\begin{array}{l}\text { Rotorua, Bay of Plenty Region, New } \\
\text { Zealand }\end{array}$ & Vermont, United States \\
\hline Resource units & Nitrogen & Nitrogen & Phosphorus \\
\hline Resource system & $\begin{array}{l}\text { Mostly extensive pasture-based } \\
\text { beef and sheep farms with some } \\
\text { dairy operations }\end{array}$ & $\begin{array}{l}\text { Mixture of pasture-based dairy } \\
\text { operations and sheep and beef } \\
\text { operations }\end{array}$ & $\begin{array}{l}\text { Mixture of full and } \\
\text { semiconfinement dairy, } \\
\text { semiconfinement cattle, } \\
\text { vegetable, and other diversified } \\
\text { farm systems }\end{array}$ \\
\hline Governance System & $\begin{array}{l}\text { Variation } 5 \text { of the regional plan: } \\
\text { performance-based cap-and-trade }\end{array}$ & $\begin{array}{l}\text { Rule } 11 \text { and Proposed Plan Change } \\
10 \text { of the regional plan: } \\
\text { performance-based cap-and-trade }\end{array}$ & $\begin{array}{l}\text { Act } 64 \text { and the Required } \\
\text { Agricultural Practices: practice- } \\
\text { based regulation }\end{array}$ \\
\hline Users & Farmers & Farmers & Farmers \\
\hline $\begin{array}{l}\text { Social, economic, } \\
\text { political setting }\end{array}$ & $\begin{array}{l}\text { - No subsidies for agriculture } \\
\text { (Quinn et al. 2009) } \\
\text { - International export-based } \\
\text { market (Quinn et al. 2009) } \\
\text { - Public pressure on agriculture, } \\
\text { and dairy in particular, to reduce } \\
\text { water quality impacts (Holland } \\
\text { 2015) } \\
\text { - National Policy Statement for } \\
\text { Freshwater in 2011/2014 mandates } \\
\text { water quality limits across country } \\
\text { by } 2025 \text { (MftE 2014 } \\
\text { - Taupo was the first nonpoint } \\
\text { source (NPS) trading program in } \\
\text { the world (Kerr et al. 2015) }\end{array}$ & $\begin{array}{l}\text { - No subsidies for agriculture (Quinn } \\
\text { et al. 2009) } \\
\text { - International export-based market } \\
\text { (Quinn et al. 2009) } \\
\text { - Public pressure on agriculture, and } \\
\text { dairy in particular, to reduce water } \\
\text { quality impacts (Holland 2015) } \\
\text { - National Policy Statement for } \\
\text { Freshwater in 2011/2014 mandates } \\
\text { water quality limits across country } \\
\text { by } 2025 \text { (MftE 2014) } \\
\text { - Rotorua early adopter of water } \\
\text { quality regulation for agricultural } \\
\text { NPS (behind Taupo and some other } \\
\text { regions) }\end{array}$ & $\begin{array}{l}\text { - Many agricultural subsidies, } \\
\text { including incentives and } \\
\text { programs to adopt conservation } \\
\text { practices (McDowell et al. 2016) } \\
\text { - Most agricultural products are } \\
\text { sold out of state, with less } \\
\text { exposure to international } \\
\text { markets than NZ farmers } \\
\text { (Wironen et al. 2018) } \\
\text { - Public finger pointing at dairy } \\
\text { as the problem for water quality } \\
\text { in Lake Champlain and other } \\
\text { waterbodies throughout the state } \\
\text { (Smith et al. 2008, Flagg 2015) }\end{array}$ \\
\hline
\end{tabular}

${ }^{\dagger}$ The National Policy Statement for Freshwater Management was further amended in 2017 but at the time of the interviews only the 2014 version of the National Policy Statement was in effect.

(BOPRC 2016). With declining water quality in the Rotorua Lakes, the Bay of Plenty regional council passed Rule 11 of the region's Water and Land Plan in 2005. The water quality goal in the plan is based on the Trophic Level Index (TLI), a composite index comprising total nitrogen, total phosphorous, chlorophyll $a$, and Secchi depth (Burns et al. 2009). The target TLI for the watershed is 4.2. Reductions in total nitrogen and total phosphorous loads to the lake are needed to achieve this TLI. Rule 11 put a "line in the sand" and capped farm nitrogen and phosphorous discharges at their current levels. Further rules, the focus of this study, Proposed Plan Change 10 (to the Bay of Plenty Regional Natural Resources Plan), were notified in February 2016. These rules managed activities that contribute nitrogen to Lake Rotorua with an aim to reduce the overall amount of nitrogen leaching in the watershed from its current load of 755 $\mathrm{tN} / \mathrm{yr}$ to its sustainable load of $435 \mathrm{tN} / \mathrm{yr}$ (BOPRC 2016). As of August 2020, the rules are still not yet operational, but will likely be in late 2020. Proposed Plan Change 10 is a performance-based cap-and-trade program for nitrogen and includes a nitrogen discharge allowance for each farm. An incentive scheme complements Plan Change 10, which features a NZD\$40 million fund set up to buy nitrogen off landowners who want to permanently lower their nitrogen discharge. The goal of the scheme is to purchase $100 \mathrm{tN}$ by 2022 , which is $13 \%$ of the current watershed N load (Rotorua Te Arawa Lakes Programme 2014).
Unlike Taupo, Rotorua farmers must make mandatory reductions in their nitrogen leaching rates to achieve an additional $140 \mathrm{tN}$ reduction.

\section{Vermont, USA}

The state of Vermont is located in the northeastern USA on the border with Canada and has a spatial extent of $23,871 \mathrm{~km}^{2}$ (U.S Census Bureau 2010). Vermont's water quality policy is statewide, but it was motivated by the phosphorus-driven eutrophication of Lake Champlain. Water quality in Lake Champlain has been on the decline for decades because of agricultural intensification and urban development (USEPA 2016). Vermont's agricultural industry includes over 6500 farms, made up of dairy, cattle, and vegetable farms, with over 800 dairy farms dominating agricultural land use and economic output (VDPC 2015, USDA-NASS 2017). Approximately 20\% of Vermont is in agriculture, $78 \%$ is in forestry, and $2 \%$ is in developed land uses (University of Vermont Spatial Analysis Laboratory 2019). In 2015, the Vermont legislature passed Act 64, which requires farms to comply with the Required Agricultural Practices (RAPs) to reduce phosphorus runoff from farms (VGA. 2015). The RAPs include mandatory practices, such as writing nutrient management plans, cover crop requirements for highly erodible soils, manure spreading bans, and 25 foot $(7.5$ meter) buffers between farm fields and surface waters (VAAFM 2018). Under the new rules, farms were required to register with the state, pay 
Fig. 1. Land use maps and water quality trends in Missisquoi watershed, Vermont, Lake Taupo, and Lake Rotorua watersheds. Figures (a), (c), and (e) shows land use split between agriculture, forest, and developed land in (a) Missisquoi watershed, Vermont (Multi-Resolution Land Characteristics Consortium 2016), (c) Lake Taupo watershed, New Zealand, and (e) Lake Rotorua watershed, New Zealand (Landcare Research New Zealand Ltd 2015). Note that the Vermont policy is implemented at the state level across all watersheds (see subset of Vermont state in Figure a), but for the purpose of land use, we show one Vermont watershed, the Missisquoi, here at a similar scale to the Taupo and Rotorua watersheds. Figures b, d, and f show corresponding long-term water quality trends, by the regionally relevant management metric, in (b) Missisquoi watershed, Vermont (Vermont Department of Environmental Conservation 2020), (d) Lake Taupo watershed, New Zealand (Verburg and Albert 2019), and (f) Lake Rotorua watershed, New Zealand (BOPRC 2020). The black dashed lines represent upper water quality thresholds for desired water quality, with the red portion of the plot representing the water quality above the threshold (BOPRC 2018, LCBP 2018, WRC 2011). Note that plot (b) is total phosphorus, the nutrient of concern in Vermont, plot (d) is total nitrogen, the nutrient of concern in Lake Taupo, and plot (f) is the Trophic Level Index (TLI) in the large black points for Lake Rotorua. Lake Rotorua manages to the TLI, a composite measure of total nitrogen (TLn), total phosphorus (TLp), secchi depth (TLs), and chlorophyll $a$ (TLc), with each of these converted to the same scale via the trophic level equation. The gold lines represent the date at which policy in each region became operational, as the Rotorua policy is not yet operational, there is no gold line in plot (f).

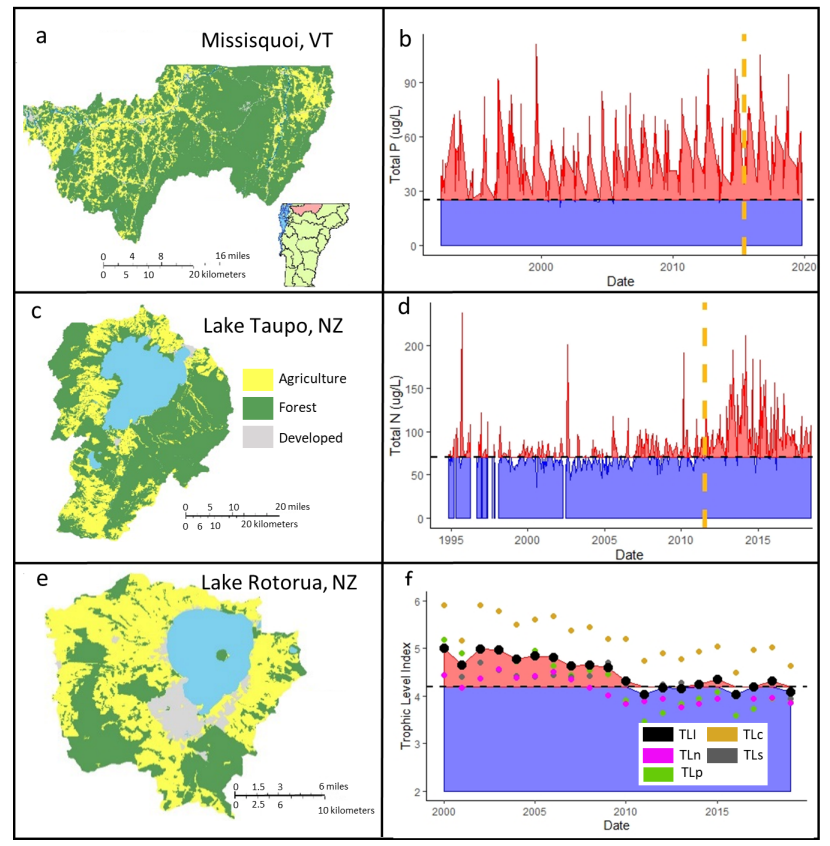

an annual fee, and are monitored for compliance with the RAPs. Monitoring frequency is dependent on farm size: every year for large farms ( $>700$ dairy cows or equivalent, e.g., 1000 beef cattle), every three years for medium size farms $(<700$ and $>200$ dairy cows or equivalent), and every seven years for small farms $(<200$ dairy cows or equivalent) (VAAFM [date unknown]).

\section{METHODS}

\section{Data collection}

We completed a total of 38 semistructured interviews with farmers in Vermont and NZ (Table 2) between 2016 and 2018. The number of interviews in each region is fairly balanced, but the number of farmers interviewed in Vermont represents a much smaller proportion Vermont's farming population compared to the NZ samples. An interview protocol was used as a basis for the semistructured interviews, which included questions about the farm system, nutrient management changes, drivers of changes, and perceptions of the broader water quality and policy in the watershed (see Appendix Table A1.1 for interview protocol). Interviews ranged between 30 minutes and 3 hours, and each was recorded and transcribed. This study received exempt certification from the University of Vermont's Institutional Review Board.

Farmer participants were selected using maximum variation sampling to purposely interview participants that represented a diversity of farm types and sizes (Collins 2010). We identified an initial list of potential participants in each region with assistance from agricultural extension agents and regional government employees. We then used snowball sampling to recruit additional participants and, in Vermont only, recruited via a government agriculture newsletter and the Vermont Farm Bureau. By farm size, the sample is skewed toward smaller farms in Vermont, which is representative of farm size distribution across the state (USDANASS 2017). Alternatively, farm size distribution in the Taupo and Rotorua samples is skewed toward larger farm sizes, according to Vermont's size definitions as noted below Table 2 . This, however, is only meant to be used as a point of comparison because in general, NZ's farms are larger than Vermont's. The average number of dairy cows on a farm in Vermont is 155 (VDPC 2015), whereas the average number of dairy cows on a farm on the North Island of NZ is 352 cows (LIC and DairyNZ 2018).

\section{Data analysis}

Content analysis

Interview transcripts were analyzed using directed, i.e., theorydriven, qualitative content analysis (Hsieh and Shannon 2005) in NVivo 12 (QSR International Pty Ltd 2018), followed by network analysis to identify themes (Pokorny et al. 2018). We used Delgado-Serrano and Ramos's (2015) definition of the SES framework as a starting point for the content analysis. We also allowed for subcategories to emerge in the coding process. See Appendix Table A1.2 for the full codebook used in the analysis.

To capture farmers' nutrient management behavior as an indicator of institutional fit between the aims of the policy and the behavioral actions needed to achieve those aims, we coded any self-reported change in nutrient management in the last 5-10 years or planned changes to occur in the next two years. We categorized nutrient management behavior into one of three categories: management, structural, or system changes (Table 3). 
Table 2. Interview sample across regional policy contexts

\begin{tabular}{|c|c|c|c|c|}
\hline \multirow[b]{2}{*}{ Farmers interviewed } & \multirow[b]{2}{*}{ All } & \multicolumn{3}{|c|}{ Region } \\
\hline & & Vermont & Taupo & Rotorua \\
\hline Total & 38 & 16 & 11 & 11 \\
\hline \multicolumn{5}{|l|}{ By farm type } \\
\hline Dairy & 23 & 11 & 3 & 9 \\
\hline Beef, sheep, or deer & 14 & 4 & 8 & 2 \\
\hline Vegetable & 1 & 1 & 0 & 0 \\
\hline \multicolumn{5}{|l|}{ By farm size ${ }^{\dagger}$} \\
\hline$>200$ dairy cows or equivalent & 11 & 11 & 0 & 0 \\
\hline$<700$ and $>200$ dairy cows or equivalent & 12 & 4 & 4 & 4 \\
\hline$>700$ dairy cows or equivalent & 15 & 1 & 7 & 7 \\
\hline \multicolumn{5}{|c|}{$\begin{array}{l}\text { 'Farm size categories are based on Vermont’s designation (VAAFM [date unknown]). Dairy cow } \\
\text { equivalents refer to the equivalent of other species in the units of dairy cows, for example, } 700 \text { dairy } \\
\text { cows is equivalent to } 1000 \text { beef cattle. New Zealand farm size designations are typically reported in } \\
\text { hectares. Because animal units were recorded in the interviews, it serves as a common unit of } \\
\text { comparison. }\end{array}$} \\
\hline
\end{tabular}

These categories reflect a spectrum in capital expense and time commitment required to make the changes, as well as the reversibility of the changes, e.g., management changes are generally less capital/time intensive and more reversible compared to structural, and structural less than system. The spectrum also captures variation in the potential reduction in nutrient losses that one would expect to see from a nutrient management change.

As noted in Table 1, the case study sites differ in their focal nutrient of concern, i.e., Vermont's rules address phosphorus and NZ's rules address nitrogen. Differences in nutrient cycles have implications for management: phosphorus's main transport pathway off a farm is through runoff via soil erosion and overland water flow, whereas nitrogen's is through leaching into groundwater and subsurface flow (Carpenter et al. 1998, Mcdowell et al. 2009). The categorization of behaviors shown in Table 3 was designed to capture a range of behaviors appropriate for both nitrogen and phosphorus management. Additionally, we would expect the trends in capital investment, reversibility, and potential nutrient reduction associated with the different categories of nutrient management changes to hold true regardless of nutrient.

\section{Regional mental model network analysis}

We grouped interviews by region and used NVivo 12's matrix query tool to export three regional aggregate, weighted, nondirectional adjacency matrices. Following methods adapted from Hoffman et al. (2014) and Pokorny et al. (2018), adjacency matrices for each region were imported into $\mathrm{R}$ version 3.5.1 ( $\mathrm{R}$ Core Team 2018) and analyzed as regional mental model network graphs using the igraph package (Csardi and Nepusz 2006). The adjacency matrices report the co-occurrence of drivers, behaviors, and outcomes in the grouped interviews for a region. In the aggregate matrices for each region each node represents a concept, i.e., SES driver, behavior, or outcome, the link between them represents a connection between those concepts, and the weight of the link represents the number of participants in a region who made a connection between the two concepts.
Regional mental model networks were analyzed using network node statistics: occurrence probability and strength. The occurrence probability of a node represents the likelihood that a node is included in the network, and therefore the extent to which a node resonates across a regional sample. It is calculated as the ratio of farmers that mentioned the node to the total number of farmers in a region's sample (Hoffman et al. 2014). Strength reflects both the breadth and prominence of a node, combining the occurrence probability and the number of nodes that a node is connected to, i.e., the "degree," in a single metric: the sum of the weights of links for all links connected to a node (Csardi and Nepusz 2006). Finally, to examine which SES subcategories were most influential in driving nutrient management behavior, we analyzed a subset graph with only drivers and behaviors, i.e., no outcomes. In this subset graph, we ranked drivers in each region by node strength. The network visualizations for each of the three regions are in Appendix Figures A1.1 to Figure A1.6.

\section{RESULTS}

\section{Behavior changes}

Farmers across all regions reported making behavioral changes to decrease nutrient loss on their farms. On average, farmers in Vermont made 5.8 behavioral changes each, farmers in Taupo made 4.6 behavioral changes each, and farmers in Rotorua made 3.6 behavioral changes each (Table 4). Farmers across all three regions made management changes, but Taupo farmers favored system changes (versus structural changes), whereas Vermont farmers favored structural changes. Rotorua farmers did not show a preference for structural versus system changes.

Some behaviors are specific to each region and agricultural systems. These practices include soil sampling (VT), no-till (VT), manure spreading (VT), installing a new barn or updating barn structures to mitigate runoff (VT), and grazing animals off pasture or farm for a period time to reduce nutrient leaching (NZ). 
Table 3. Categories of nutrient management behavior changes on farms.

\begin{tabular}{lll}
\hline \hline Category & Definition & Examples of changes in category \\
\hline Management & $\begin{array}{l}\text { Changes to crop or animal types, plus } \\
\text { practices related to soil and animal } \\
\text { management }\end{array}$ & $\begin{array}{l}\text { Includes changes in timing and amount of fertilizer applied, } \\
\text { changes in the cropping rotation, stocking rate of animals, type } \\
\text { and amount of animal feed, and grazing animals on or off } \\
\text { farm. }\end{array}$ \\
Structural & Farm physical or infrastructure changes \\
& $\begin{array}{l}\text { Includes edge-of-field and riparian buffers, stock exclusion from } \\
\text { waterways, new milking parlor, new effluent system, water } \\
\text { retention bunds, and animal stand-off pads. }\end{array}$ \\
System & $\begin{array}{l}\text { Change in overall farm dynamics, including } \\
\text { type of product and expansion or } \\
\text { contraction of land base }\end{array}$ & $\begin{array}{l}\text { sheep, sheep milking, and forestry, transition to organic or } \\
\text { grass-based system, land retirement, purchase of new land, and } \\
\text { sale of land. }\end{array}$ \\
\hline
\end{tabular}

${ }^{\dagger}$ Grazing animals on or off the farm involves moving animals in order to protect wet pasture from damage.

\section{Management changes}

The top two management change categories for all three regions were seeding varieties/cropping changes and fertilizer changes (Fig. 2). Reduced animal stocking rate was a relatively common management change in Taupo and Rotorua, but no farmers in Vermont reduced their animal numbers. Only Vermont farmers and one Rotorua farmer started nutrient management planning and soil sampling. Across all three regions a small number of farmers engaged in pursuing nutrient management knowledge. All of the behaviors noted thus far would be considered behaviors that would be expected to reduce farm nutrient losses. However, there were two categories of behavior reported where nutrient losses would be expected to increase: increased fertilizer use and increased stocking rate. In Taupo and Vermont, one and two farms respectively increased fertilizer use, and two farms in Vermont also increased their stocking rate, i.e., the number of animal units on their farm.

Fig. 2. Percentage of sample reporting management changes by region.

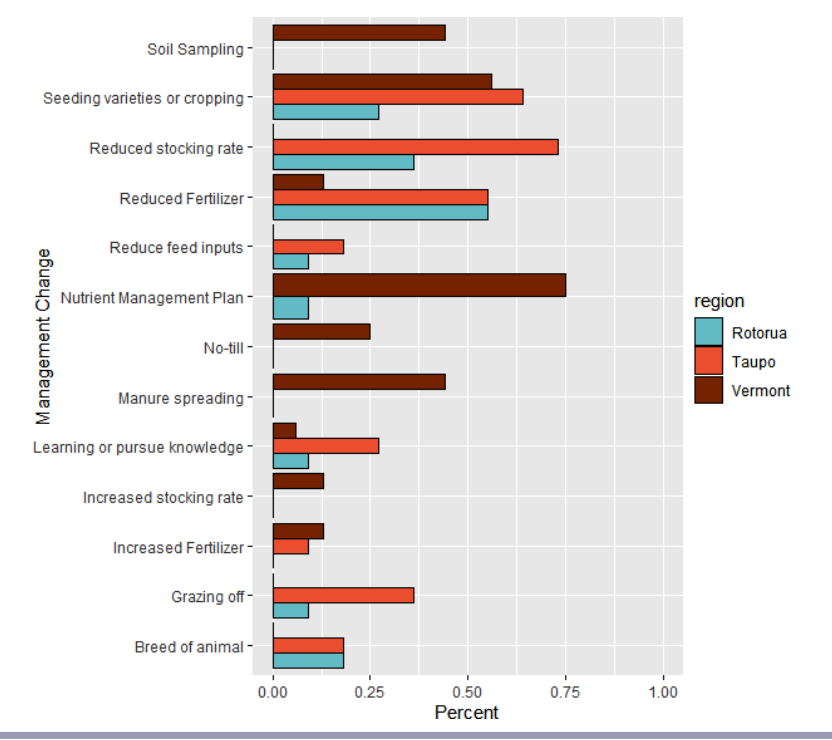

\section{Structural changes}

Vermont farmers made the most structural changes on average (Fig. 3). The structural changes in common across the three regions were fencing and purchasing new equipment, e.g., more efficient irrigator. The top structural changes for Vermont were buffers and setbacks, manure pit or pad upgrades, leachate systems, and water flow control structures. In Rotorua, manure pits or pad upgrades were the top structural change. In Taupo, relatively few structural changes were made, but the few included milking parlor upgrades, equipment upgrade, and fencing.

Fig. 3. Percentage of sample reporting structural changes by region.

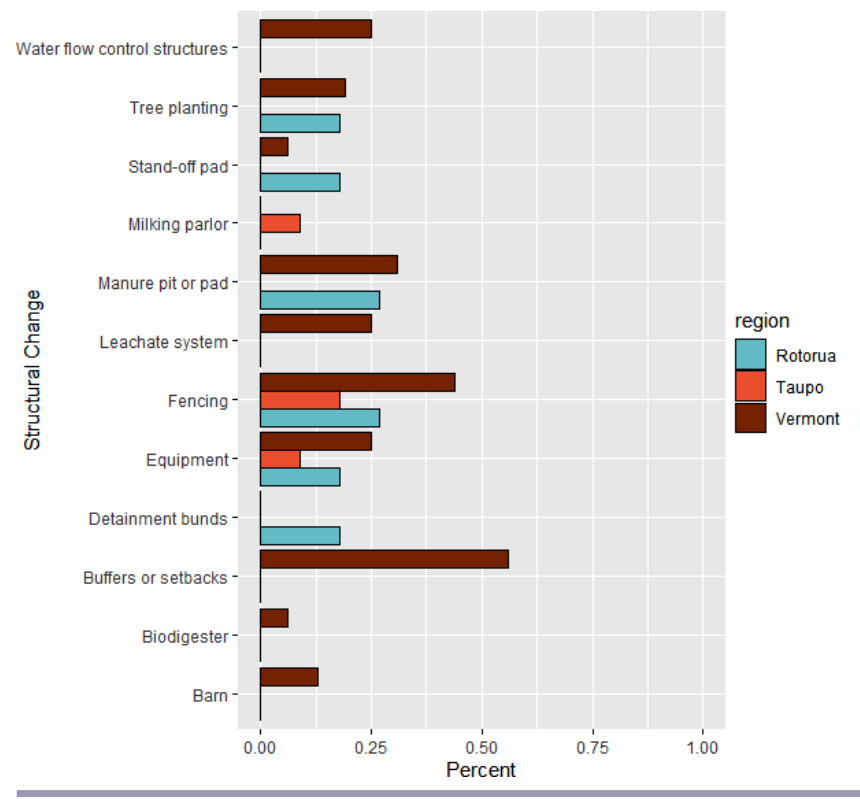

\section{System changes}

The top system changes across all three regions were switching to a lower nutrient loss farm system and the purchase or lease of new land (Fig. 4). In Vermont, three farms transitioned to systems with lower nutrient losses, i.e., grass-fed or organic dairies. In 
Table 4. Count of nutrient management changes and average number of behavior changes per person by region.

\begin{tabular}{|c|c|c|c|c|c|c|}
\hline \multirow[b]{2}{*}{ Behavior change } & \multicolumn{2}{|c|}{ Vermont $(n=16)$} & \multicolumn{2}{|c|}{ Taupo $(n=11)$} & \multicolumn{2}{|c|}{ Rotorua $(\mathrm{n}=11)$} \\
\hline & Count & $\begin{array}{c}\text { Average } \\
\text { (std. dev.) }\end{array}$ & Count & $\begin{array}{c}\text { Average } \\
\text { (std. dev.) }\end{array}$ & Count & $\begin{array}{c}\text { Average } \\
\text { (std. dev.) }\end{array}$ \\
\hline Management changes & 46 & $2.9(1.0)$ & 33 & $3.0(1.8)$ & 19 & $1.7(1.4)$ \\
\hline Structural changes & 40 & $2.5(1.7)$ & 4 & $0.4(0.6)$ & 14 & $1.3(1.2)$ \\
\hline System changes & 10 & $0.6(0.7)$ & 19 & $1.7(0.6)$ & 11 & $1.0(1.0)$ \\
\hline Total changes & 93 & $5.8(2.5)$ & 50 & $4.6(1.5)$ & 40 & $3.6(1.9)$ \\
\hline
\end{tabular}

Rotorua, four farms were converted to forestry or transitioned from dairy to sheep and beef cattle grazing. Finally, in Taupo, six farms converted to exotic forestry (pine) or native forest or transitioned from dairy support or cattle breeding systems to beef finishing systems. Taupo and Rotorua farmers reported some land was sold or no longer being leased, but Vermont farmers did not. Although it should be noted that two of the three farmers who sold farm land in Taupo also purchased other farm land in the watershed. So, these farmers did not exit farming in the watershed. Importantly, there were three instances in Taupo and Rotorua where farmers shifted to a higher nutrient leaching farm system, including transitions to dairy, sheep milking, and cattle breeding operations. Similarly, in Vermont there were two cases in which a farmer transitioned from forestry into agricultural production.

Fig. 4. Percentage of sample reporting system changes by region.

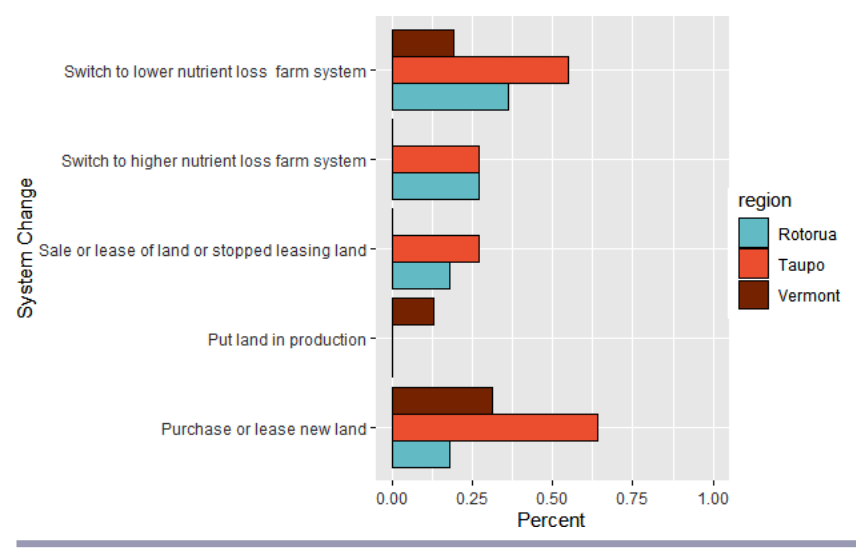

\section{Behavioral drivers}

Overall, Taupo and Vermont farmers referenced 19 different SES subcategories as behavioral drivers, whereas Rotorua farmers referenced 16 (see Appendix 1 Table A1.3 and Table A1.4 for all driver node statistics). Not all SES subcategory drivers were present in each of the regions. However, in general, farmers in each region referenced many of the same drivers (Table 5). We define key drivers as those drivers that ranked in the top five drivers by strength in at least one region.

\section{Governance drivers}

Water quality policy is the top ranked behavior driver in Taupo and Rotorua, and the second in Vermont. In both Taupo and
Rotorua, the occurrence probability is $100 \%$ : every farmer interviewed referenced water quality policy as a driver of behavior. In Vermont, there was also a very high occurrence probability of $94 \%$. The following three quotes, one from each region, demonstrate the influence of each region's water quality policy on behavior:

Some of my land, I'm on the early spreading ban. Due to the new Required Agricultural Practices, I got to hit them [with manure spreading] in the midsummer, so we're changing the way we got to do things, a little bit. We'll see in a few years. Hopefully, it'll benefit. Vermont Farmer

But when Rule 11 came in ... we [got rid of] 230 cows and 2 full time jobs. That was a result of [the water quality policy] because we were leasing land. We were leasing land and then with the [the water quality policy] we needed to get out of the catchment, which we've done. Rotorua Farmer

We bought the farm and farmed it for a couple of years and through [the] consultation process, it was pretty obvious that it was going to be capped, and it might be worse than that, we weren't sure what was going to come out of that ... So we decided after a lot of soul-searching that we would sell. Taupo Farmer

In Vermont, instead of water quality policy, government agency assistance had the highest strength rating and an occurrence probability of $88 \%$. In Rotorua, government agency assistance was also relatively influential, ranked fourth amongst drivers with an occurrence probability of $45 \%$, however, in Taupo, it ranked 10 th, with an occurrence probability of only $18 \%$. Farmers in Vermont reported government agency assistance mainly from the U.S. Department of Agriculture's (USDA) Natural Resources and Conservation Service (NRCS) programs that give financial assistance for adopting, upgrading, or installing new practices/ structures on the farm, as well as technical assistance. In Rotorua, farmers referenced some financial assistance from the Regional Council to install physical structures on their farms such as fencing or water detainment berms, as well as funding to write farm management plans. The following quote represents the strong influence that NRCS played in driving behavior change for many Vermont farmers in the sample:

So, [ the NRCS agent ] just stopped in one day and they're nonregulatory. It was just a total social visit and I said,

"Well, I've got some concerns". .. So, he really listened to me and said, "Yeah, let's go for it. Let's do it." So, 


\section{[the USDA NRCS' Environmental Quality Incentives Program] project is maxed out at $\$ 250,000.00$ at the time. Well, we maxed it out. Vermont Farmer}

NGOs and other organizations ranked third amongst behavioral drivers in Vermont, sixth in Rotorua, and 11th in Taupo. Seventyfive percent of farmers in Vermont referenced technical assistance from the University of Vermont (UVM) agricultural extension and organic certification programs, or financial assistance from watershed programs and land trusts. One Vermont farmer noted a sentiment about UVM Extension, which was shared by many in the Vermont sample: "They're really, really helpful." In Rotorua, only $36 \%$ of farmers cited NGOs and other organizations as drivers, but they included similar categories of organizations, such as land trusts, research organizations like AgResearch, and industry extension like DairyNZ. The other two governance nodes, other government policies and participation in a farmer group, were not listed in the top five of behavioral drivers in any region.

\section{Actor drivers}

Actor economics was an important driver across all three regions. This driver represents a farm or farmer's economic situation as opposed to broader market considerations like price. Aside from actor economics, no other actor subcategory drivers were listed amongst the top five behavioral drivers in any region. These other actor drivers include ethics, flexibility, leadership or entrepreneur, lifestyle, past experience, social attributes, and technology.

Actor economics, in terms of node strength, ranked second in Taupo with a $91 \%$ occurrence probability, second in Rotorua with a $64 \%$ occurrence probability, and fifth in Vermont with a $50 \%$ occurrence probability. Actor economic drivers were phrased in similar language across all three regions. One Vermont farmer, while describing a transition from forested land into agricultural land, said, "the biggest driver is getting the most out of every dollar." In Rotorua, when explaining reduced use of nitrogen fertilizer, a farmer stated, "it was just around maximizing profit." Finally, in Taupo, one farmer described their reason for leasing out their land as "money, money, and money."

\section{Resource system and resource unit drivers}

Ecological drivers, such as drought, flooding, and erosion, were ranked as top five drivers across all three regions. In Rotorua ecological drivers were ranked third, including protecting native species, minimizing runoff, and reducing erosion. In Vermont, ecological drivers were ranked fourth including soil health, minimizing runoff, stabilizing streambanks, concerns over water quality, and controlling erodible soils. Last, In Taupo, ecological drivers were ranked fifth, with many farmers referencing the influence of multiple years of drought. Farm production needs were not listed as a key behavioral driver in any of the three regions.

Nitrogen and phosphorus attributes were ranked relatively higher in Rotorua (fifth) and Taupo (eighth) than Vermont (12th). Only one farmer interviewed in Vermont referenced attributes of phosphorus as driving behavior, i.e., the specifics of nutrient cycling. In contrast, a small subset of farmers in Rotorua and Taupo cited a sophisticated understanding of nutrient dynamics as driving behavior change.
Social, economic, and political setting drivers

The nitrogen market subcategory was very influential in Taupo. This code was specific to the existing voluntary nitrogen market in Taupo that was established as a part of the water quality policy. The nitrogen market is ranked third as a behavioral driver in Taupo, with an occurrence probability of $82 \%$. One farmer in Rotorua referenced concrete plans to sell nitrogen in the newly formed nitrogen market in Rotorua. There is no current market for nitrogen or phosphorus in Vermont.

Broader economic and market drivers, such as price, market access, and competition were ranked fourth as a behavioral driver in Taupo and eighth in Vermont and Rotorua. The other four drivers in this category, including social context, industry, or consultant advice, demographic shifts, and carbon market, were ranked relatively low across the three regions.

\section{Outcomes}

\section{Individual outcomes}

At the individual level, Taupo farmers reported more negative and as well as more positive economic outcomes on average than Rotorua and Vermont farmers in the sample (see Fig. 5). Across the regions these included compliance costs, farm viability, financial impacts, and impacts to farm economic flexibility. One Vermont farmer referenced a negative financial impact related to requirements under the water quality policy, when they said, "The biggest problem I have is we have to put a leachate system in. Ugh. It's an $\$ 81,000$ project, which I don't think is even needed," but later clarified that they wouldn't pay the full cost of the project. Some positive outcomes included improved farm viability, beneficial financial impacts, better farm economic flexibility, and access to new markets. One Taupo farmer said, "To me it's been a windfall. We bought land cheaper. We made some very clever smart moves, so it's opened up huge opportunities for me as a person." Several farmers in Vermont and Rotorua mentioned that the water quality policy had neutral impact compliance costs for their farm.

Fig. 5. Percentage individual outcomes by region.

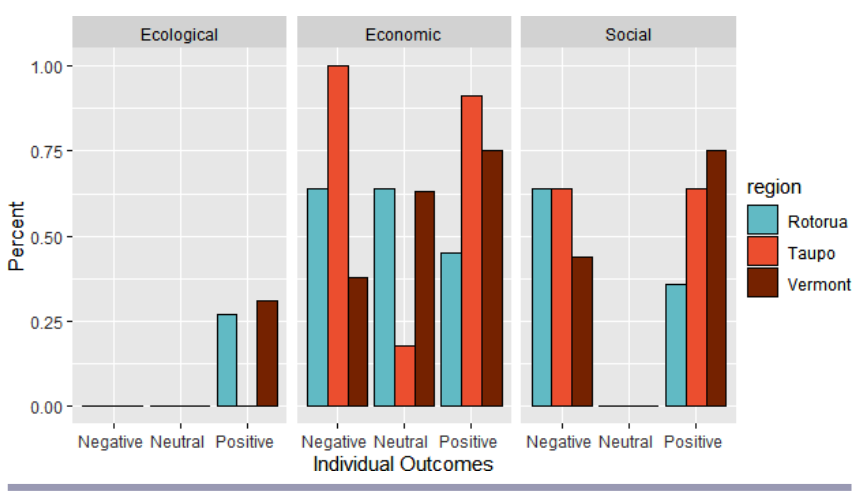

In terms of individual social outcomes, Vermont farmers on average reported more positive outcomes than Taupo and Rotorua and fewer negative outcomes than Taupo and Rotorua. Farmers reported increased knowledge and awareness, nonfinancial benefits such as pride, and recognition for environmental stewardship. For negative individual social outcomes, farmers mentioned distrust in regulation, nonfinancial 
Table 5. Key behavioral driver node statistics. Key drivers are those that are ranked by strength in the top five of drivers in at least one of the three regions. Lack of statistics for a node in a region means that a node was not mentioned in the region.

\begin{tabular}{|c|c|c|c|c|c|}
\hline & Node description & Node statistics & Taupo & Vermont & Rotorua \\
\hline $\begin{array}{l}\text { Water quality policy } \\
\text { (governance) }\end{array}$ & $\begin{array}{l}\text { The specific water quality policy in each } \\
\text { region (i.e., Taupo's Variation 5, Vermont's } \\
\text { Act } 64 \text { and the RAPs, and Rotorua's Rule } \\
11 \text { and Proposed Plan Change 10) }\end{array}$ & $\begin{array}{l}\text { Rank } \\
\text { Strength } \\
\text { Occurrence } \\
\text { probability }\end{array}$ & $\begin{array}{c}1 \\
88 \\
100 \%\end{array}$ & $\begin{array}{c}2 \\
58 \\
94 \%\end{array}$ & $\begin{array}{c}1 \\
42 \\
100 \%\end{array}$ \\
\hline $\begin{array}{l}\text { Government assistance } \\
\text { (governance) }\end{array}$ & $\begin{array}{l}\text { Technical or financial assistance from a } \\
\text { government agency/entity }\end{array}$ & $\begin{array}{l}\text { Rank } \\
\text { Strength } \\
\text { Occurrence } \\
\text { probability }\end{array}$ & $\begin{array}{c}10 \\
9 \\
18 \%\end{array}$ & $\begin{array}{c}1 \\
74 \\
88 \%\end{array}$ & $\begin{array}{c}4 \\
14 \\
45 \%\end{array}$ \\
\hline Economics (actor) & $\begin{array}{l}\text { Microeconomic considerations tied to a } \\
\text { farm or farmer's economic situation, e.g., } \\
\text { income, debt, and economic efficiency of } \\
\text { farm }\end{array}$ & $\begin{array}{l}\text { Rank } \\
\text { Strength } \\
\text { Occurrence } \\
\text { probability }\end{array}$ & $\begin{array}{c}2 \\
49 \\
91 \%\end{array}$ & $\begin{array}{c}5 \\
21 \\
50 \%\end{array}$ & $\begin{array}{c}25 \\
2 \\
64 \%\end{array}$ \\
\hline $\begin{array}{l}\text { Ecological } \\
\text { (resource system) }\end{array}$ & $\begin{array}{l}\text { Existence, mitigation, or prevention of } \\
\text { erosion, runoff, drought, flooding, etc. }\end{array}$ & $\begin{array}{l}\text { Rank } \\
\text { Strength } \\
\text { Occurrence } \\
\text { probability }\end{array}$ & $\begin{array}{c}5 \\
31 \\
45 \%\end{array}$ & $\begin{array}{c}4 \\
31 \\
44 \%\end{array}$ & $\begin{array}{c}3 \\
17 \\
55 \%\end{array}$ \\
\hline $\begin{array}{l}\text { Nitrogen market } \\
\text { (social, economic, } \\
\text { political setting) }\end{array}$ & $\begin{array}{l}\text { Purchase or sale of nitrogen in Taupo's } \\
\text { nitrogen market or future purchase or sale } \\
\text { in Rotorua's nitrogen market }\end{array}$ & $\begin{array}{l}\text { Rank } \\
\text { Strength } \\
\text { Occurrence } \\
\text { probability }\end{array}$ & $\begin{array}{c}3 \\
42 \\
82 \%\end{array}$ & $\begin{array}{l}- \\
-\end{array}$ & $\begin{array}{c}10 \\
2 \\
9 \%\end{array}$ \\
\hline $\begin{array}{l}\text { NGOs or other } \\
\text { organizations } \\
\text { (governance) }\end{array}$ & $\begin{array}{l}\text { Interactions with nongovernmental entities } \\
\text { including extension, watershed programs, } \\
\text { land trusts, and research organizations, and } \\
\text { universities }\end{array}$ & $\begin{array}{l}\text { Rank } \\
\text { Strength } \\
\text { Occurrence } \\
\text { probability }\end{array}$ & $\begin{array}{c}11 \\
7 \\
9 \%\end{array}$ & $\begin{array}{c}3 \\
48 \\
75 \%\end{array}$ & $\begin{array}{c}9 \\
6 \\
36 \%\end{array}$ \\
\hline $\begin{array}{l}\text { Economics and } \\
\text { markets (social, } \\
\text { economic, political } \\
\text { setting) }\end{array}$ & $\begin{array}{l}\text { Macroeconomic and market dynamics } \\
\text { including prices, market access, and } \\
\text { competition }\end{array}$ & $\begin{array}{l}\text { Rank } \\
\text { Strength } \\
\text { Occurrence } \\
\text { probability }\end{array}$ & $\begin{array}{c}4 \\
40 \\
82 \%\end{array}$ & $\begin{array}{c}8 \\
9 \\
44 \%\end{array}$ & $\begin{array}{c}8 \\
5 \\
9 \%\end{array}$ \\
\hline $\begin{array}{l}\text { Nitrogen and } \\
\text { phosphorus attributes } \\
\text { (resource units) }\end{array}$ & $\begin{array}{l}\text { Attributes of nitrogen and phosphorus and } \\
\text { the movement of these nutrients in the } \\
\text { landscape and farm system }\end{array}$ & $\begin{array}{l}\text { Rank } \\
\text { Strength } \\
\text { Occurrence } \\
\text { probability }\end{array}$ & $\begin{array}{c}8 \\
16 \\
27 \%\end{array}$ & $\begin{array}{c}12 \\
2 \\
6 \%\end{array}$ & $\begin{array}{c}5 \\
11 \\
27 \%\end{array}$ \\
\hline
\end{tabular}

costs like time, stress, and mental health impacts, uncertainty in the future of their farming livelihoods, and a few farmers in Rotorua mentioned feeling like they were unfairly impacted by the water quality policy at a personal level.

No negative ecological outcomes at the farm scale were reported in any region as a result of their behavior changes or the water quality policy. However, a few farmers in Vermont and Rotorua, but not Taupo, referenced positive ecological change on their farms in terms of pasture or soil quality, and water quality.

\section{Vermont watershed outcomes}

Vermont farmers generally perceived more positive and neutral watershed level outcomes than negative (see Fig. 6 for comparison across regions). Vermont farmers mentioned increased community awareness, community well-being, and fairness as positive social outcomes, but few reported negative community well-being. One farmer described the impact of the water quality policy on a neighbor: "And, I think it's too bad. He gets really upset about it. He's done a really good job farming all his life ... they're basically forcing him out of business." Only a few Vermont farmers noted negative or positive economic impacts. On the negative side farmers cited challenges to the agricultural community operating with regulation and low product prices, while on the positive side farmers cited financial viability with cost share assistance and flexibility in the water quality policy regulations.

Fig. 6. Percentage watershed outcomes by region.

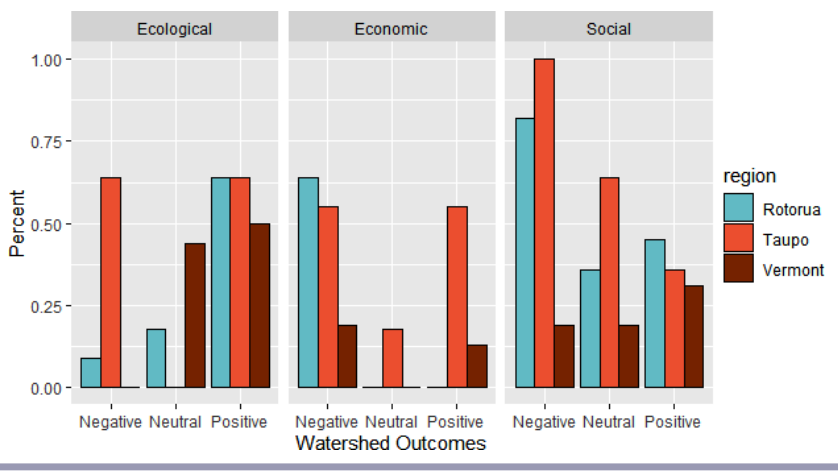


Eight Vermont farmers perceived positive watershed ecological outcomes, seven neutral, and none mentioned negative ecological outcomes. Vermont farmers in the sample appeared split as to whether management changes were being made, and some farmers said they do not see changes. One Vermont farmer said, "I go by some of the other farms that do some of the things they do, I go, "What the heck? How do they get away with that?"” Other farmers were optimistic in their outlook for water quality improvements from land use changes. Another Vermont farmer said, "I see the bigger farms, a lot of them are doing cover crops where they never did before." Most of Vermont farmers' ecological outcome reflections related to farming management changes on the landscape and not broader land use changes.

\section{Taupo watershed outcomes}

In the Lake Taupo watershed, farmers' perceptions were polarized, with high numbers of positive and negative outcomes. Socially, every farmer mentioned at least one negative outcome of the water quality policy, mostly in terms of fairness of the policy or community well-being. Reflecting on the policy process, one farmer said the "uncertainty emotionally and mentally [was] shocking ... a lot of farmers were depressed because they didn't see a lot of hope." Many farmers mentioned other farmers selling their farm and leaving the catchment during the policy process. For the large number of comparatively underdeveloped, relatively low-nitrogen leaching Māori farms in the catchment, farmers expressed that the policy was unfair. Except for freehold land purchased by Māori individuals, Māori generally cannot sell land. One farmer said: "And being a lot of Māori-owned land they went overly heavy about it because it sort of hindered what they could do with their land further down the track." Neutral watershed social perceptions included acceptance of the policy, a desire to "just get on with it." Positive social outcomes included the flexibility from allowing nitrogen trading and the ability to sell nitrogen to the trust. Selling nitrogen was seen as a positive outcome for Māori farms because it allowed them to liquidate capital without selling their land.

Perceptions of watershed economic impacts in Taupo varied greatly amongst the farmer sample, with six farmers mentioning positive and negative economic impacts and two neutral. One farmer explained how the policy limits their farm's economic potential: "Essentially, under this process we can't grow any more meat per hectare, our livestock numbers are capped at 2004 levels, and costs inexorably keep growing." Conversely, on the positive side, one farmer said, "the beauty about farming in here is that you've got a resource that comes in for 25 years. Now, I'd argue that there is nowhere in NZ that you've got a license to farm for 25 years."

Taupo farmers were split equally between negative and positive perceptions of the ecological outcomes. Farmers perceived the policy technically as a success, purchasing nitrogen out of the catchment, changing land use to reduce nitrogen leaching, and capping nitrogen in the watershed, and, in some cases, farmers thought the lake was clearing up. However, some farmers reflected negatively upon the fact that new dairy farmers were able to come into the watershed under the policy and intensify by purchasing nitrogen discharge allowances through the market. Additionally, many farmers reflected negatively upon the transition of land from pastoral agricultural to forestry under the water quality policy. As one Taupo farmer reflected, "All that now is getting developed ... That should never ever be put into trees, and it is going to end up having trees. That is wrong."

\section{Rotorua watershed outcomes}

In Rotorua, farmers in the sample perceived more positive ecological watershed outcomes, split social impacts and only negative economic impacts of the water quality policy process. Economically, seven farmers reported that the policy process has resulted in a steep decline in investment in farming in the watershed and the perception that "financially, it's not doable" to achieve the nutrient reductions required. Nine farmers perceived negative social impacts at the watershed scale including impacts on community well-being and perceived fairness of the policy. According to one Rotorua farmer, the policy process has been emotionally difficult: "So, I think - but it's like grievance; this this phase is the angry phase, and then acceptance might come because that's what happened ... in the Taupo catchment like I say." Rotorua farmers reported that the policy is unfair toward farmers and that the urban share of the burden is being overlooked. Furthermore, Rotorua farmers expressed frustration that previous actions to reduce phosphorus runoff they have undertaken voluntarily have not been given enough credit under the new policy, i.e., because the policy focuses on nitrogen reduction. Four farmers noted positive social outcomes while another four farmers noted negative social outcomes. One farmer said that as a result of the policy community awareness and wellbeing has risen: "I think that probably the biggest plus out of it is actually talking to your neighbor, and working with your neighbor, and seeing what they're doing."

Seven Rotorua farmers perceived positive ecological outcomes, with two neutral and just one negative. On the positive side, one farmer suggested that the policy halted further land use intensification: "there might have been a few more farms convert to dairy ... had [the water quality policy] not been there." In some cases, farmers reported that "most farmers have done small changes to improve areas" whereas others perceived that "the land use change in the catchment, has been minor." Although a number of Rotorua farmers noted positive ecological outcomes, similar to Vermont, the outcomes focused on management changes, not land use change.

\section{DISCUSSION}

\section{Behavioral patterns and institutional fit}

Farmers in the sample reported changing nutrient management behavior mostly to reduce nutrient losses from farms, i.e., intended direction of the policy, and the actions of these farmers are expected to improve water quality over time to meet the goals of the policy. This suggests that all three regions demonstrate a reasonable degree of biophysical fit, in which the aim of the policy, i.e., to change farmer behavior to improve nutrient outcomes, is resulting in the human actions desired. However, we do see important differences in the types of behaviors enacted under the different rule structures, which are likely to have differential impacts on water quality improvement.

First, management changes are the clear low-hanging fruit. Management changes are relatively inexpensive, more reversible, and do not necessarily require major time or financial investments. If perceived as ineffective in the short-term, e.g., because of the 
slow ecological pace of water quality improvement, these behaviors could be easily reversed. Therefore management changes do not provide strong assurance for long-term water quality impacts. As a consequence, it is not surprising that farmers across all three regions reported a number of management changes.

There are markedly different patterns in structural and system changes between the regions that are likely to have implications for biophysical fit due to differential water quality. Farmers reported more structural changes in Vermont and more system changes in NZ, whereas in Rotorua, farmers reported lower levels of both. In most cases, structural changes adjust nutrient movement pathways on the farm rather than the overall amount of nutrients used, e.g., fertilizer use, feed use, and/or animal numbers. System changes, as we see dominating in Taupo, conversely, typically impact the overall quantity of nutrients used on the farm through changing the amount required for farm production needs. Thus, it is likely that system changes represent a greater potential for reducing nutrient losses and for improved biophysical fit for the policy. Although we hypothesize there is a differential impact of these behaviors on nutrient load, ultimately this is an area where further research is needed to better understand the relationship between these structural and system changes and water quality improvements in each specific biophysical context.

\section{Interplay of water quality policy with the SES in the regional mental models}

Through examining drivers and outcomes, we find differences in the interplay between the policy and the SES context in each region's mental models. These differences are likely driving the dominance of structural versus system changes in Taupo and Vermont, as well as have implications for the social fit of the policy.

Vermont farmers described an incentive-based SES context that supports farmers with financial and technical assistance to adopt new structural practices with a regulatory backstop. Vermont's policy takes advantage of the path dependence of the cost-sharing approach to conservation in USA agri-environmental policy: the policy adds a regulatory mechanism that requires change, but still allows for financial assistance to farmers in changing behavior. In this sense, the policy is, as Ekstrom and Young (2009) state, "benefit[ing] from [the] stickiness" of pre-existing institutions, rather than working against them. Notably, because of this strong interplay, Vermont is the only region in which the water quality policy is not reported as the main driver of behavior. The design of the practice-based policy, requiring specific practices on farms, also aligns with the program structure of NRCS and other programs that pay farmers to adopt conservation practices. We hypothesize that this is the reason for very few farm system changes in the Vermont sample. Further, the heavy role of incentives in the SES context shapes the outcomes for farmers with very few negative social and economic impacts noted, alluding to high degree of social fit. However, farmers expressed mixed perceptions about whether the policy is actually having an effect ecologically and leading to long-term water quality improvements. This suggests that the policy may be trading off short-term social fit for long term biophysical fit. This may also be a symptom of broader issue of spatial fit (Galaz et al. 2008) in the Vermont policy: without farm-scale nutrient limits, there is no direct link in responsibility between the water quality at the watershed scale and individual farm contributions, making it difficult to enable and enforce systemic changes (Vatn and Vedeld 2012).

In Taupo, farmers described polarized experiences at the interplay of regulatory requirements and market dynamics that drive systemic change for the profit of some and marginalization of others. Taupo's policy regulates modeled nutrient reduction rather than the practices that reduce nutrient losses. Within this performance-based policy, structures do not "count" in the policy in the same way they do in Vermont. Furthermore, there are not the programs to assist farmers in purchasing or upgrading infrastructure. To adapt to the nutrient cap, famers in our sample were able to sell nitrogen to the voluntary nitrogen market and used the capital to change their farm system. In Taupo, both actor economics and broader economics and markets are important drivers, reflecting a challenging interplay between regulating nitrogen at the watershed scale and allowing farmers to remain competitive in the global agricultural market (Vatn and Vedeld 2012). This results in two polarized experiences: (1) many farmers are at the margin economically and struggle to offset new risks and exposure and (2) some farmers were able to take great economic advantage of the policy to further improve their economic situation. For many in the first situation, the new policy fostered entrepreneurship and innovation in a way that was not seen in the other two regions. For example, farmers were experimenting with new farm system types, like sheep milking, and new branding/marketing strategies to make up for their inability to intensify their production system. Similarly, Taupo farmers report polarized social impacts suggesting a lower degree of social fit. However, Taupo farmers did reflect some institutional acceptance through a desire to simply "get on with" the new policy.

Finally, in Rotorua, our study captured a time of high uncertainty with a strong policy signal. Rotorua's farmers cited fewer drivers than the other two regions and fewer behavioral changes. However, the water quality policy was reported as the top driver of behavior change in the region, suggesting that even though just a policy signal, i.e., the policy was not yet operational, the proposed rules were perceived as changing behavior. The strength of actor economics in driving management changes reflects that farms are pursuing the "low hanging fruit," while evaluating the potential economic impact of future changes. Like Taupo, this reflects the challenging interplay between global economics and regional nitrogen policy, exacerbated here by the policy uncertainty at the regional scale. Unlike Taupo, the regional council in Rotorua has played a role in providing cost share funding and technical assistance to farms to install some structures, mainly fencing and detainment berms on farms in the past 10 years. However, there is no cost share available for practice adoption under the new policy. As a result, farmers in our sample expressed highly negative social and economic outcomes, alluding to a very low degree of social fit at the time of the interviews. Interestingly, some farmers reported positive ecological outcomes as a result of land management changes, but again like Vermont, these were not perceived as broad landscape changes and therefore likely reflect lower biophysical fit as well. 


\section{Opportunities for fit and interplay}

Comparing across the three regions, a key takeaway is that farmers needed access to finance or financial assistance to achieve the structural and/or system changes that we hypothesize are associated with higher biophysical fit. In Vermont, farmers used financial assistance to make structural changes, in Taupo farmers sold nitrogen to enable system change, and in Rotorua, without a functioning nitrogen market or extensive financial assistance options, there were much lower levels of structural and system change. Without access to capital, our results suggest that farmers are unlikely to undertake any changes beyond management changes. Water quality policy can take advantage of interplay with pre-existing conservation schemes, like in Vermont, or design new market structures, like in Taupo, to enable structural and system changes.

Ecological drivers across the three regions played a role in nutrient management decisions under the policies. It appears as though an important part of behavior change is the alignment of nutrient management changes with ecological functioning on farm, such as drought tolerance or reducing erosion. This intuitive result can aid in promoting adoption and compliance through highlighting the biophysical fit of the behavior with both the water quality in the watershed and the functioning of the farm system.

Overall, our study presents a novel integration of the SES framework with farmer mental models to contribute four key insights for policy fit and interplay. First, the mandatory water quality rules for farms in the three regions are perceived by farmers as causally changing their behavior, suggesting that there is a fit between each policy and its aims. Second, however, the different rule structures are resulting in different patterns of nutrient management changes on the landscape, which we hypothesize will have implications for biophysical fit and effectiveness of the policy, i.e., water quality improvement, over the long term. Specifically, we hypothesize that system changes, as seen in Taupo, present greater opportunity for long-term water quality improvement as opposed to structural and management changes, and we highlight this as an area for future research. Third, although all three regions have or are implementing mandatory rules, farmers' experience of the outcomes of these policies demonstrate varying degrees of social fit, lowest in Rotorua, highest in Vermont, with some evidence for trade-offs between biophysical and social fit. Finally, the regions are each challenged by different issues of fit and interplay. Interplay with pre-existing institutions is driving behavior in Vermont, but challenging social fit in Taupo and Rotorua, and the overall spatial misfit of Vermont's policy may be driving the potential trade-off in social and biophysical fit.

\section{CONCLUSION}

Farmer behavior change is critical to improve water quality and reduce agricultural NPS pollution. In this study, we evaluated farmers' experiences and perceptions in three regions facing mandatory rules to curb agricultural NPS pollution using a novel integration of the SES framework and farmer mental models to assess policy fit and interplay. As more regions consider mandatory water quality rules to address nutrient pollution from farms, our analysis suggests that rule selection should consider (a) explicitly matching the biophysical aims of the policy with the types of behavior changes needed in the landscape to achieve the desired nutrient reductions, such as enabling system changes to improve nutrient load reduction as needed; (b) the interplay between policy rules and the current social, economic, ecological, and political drivers for nutrient management on farms, such as broader market integration that may hinder behavior change or threaten social fit; and (c) potential enablers that can interact with mandatory rules to further policy aims, such as financial incentives or support. To this last point, we find that access to capital in some form is required for farmers to achieve changes associated with higher biophysical fit. The use of this novel methodology, combining mental models analysis with SES framework-based policy analysis allows for a closer examination of the processes through which policy is changing behavior and the experienced impacts of policy change. For regions considering a shift to mandatory rules for nutrient pollution from farms, we suggest that policy design should carefully consider driverbehavior-outcome dynamics to achieve long-term water quality policy fit.

Responses to this article can be read online at: https://www.ecologyandsociety.org/issues/responses. php/12034

\section{Acknowledgments:}

The authors would like to express deep gratitude to the farmers who welcomed the lead author into their homes and shared their experiences. Additionally, we acknowledge support for the research from the US National Science Foundation's East Asian and Pacific Summer Institutes Fellowship [NSF EAPSI 1614170], NSF OIA-1556770, NSF FW-HTF-P 1929814, the Economics for the Anthropocene project, which is jointly funded by the Social Sciences and Humanities Research Council of Canada and the University of Vermont, an award from the University of Vermont Graduate College's Thomas J. Votta Memorial Fund, and grants from the University of Vermont James M. Jeffords program and the Vermont Water Resources and Lake Studies Center. We would also like to thank Andrew Wagner for his assistance in creating the land use maps in Figure 1. Finally, we would like to thank Caitlin Morgan and Christine Carmichael for their feedback on a draft of the manuscript.

\section{Data Availability:}

The data that support the findings of this study are available on request from the corresponding author, CRHW. None of the data are publicly available because of their containing information that could compromise the privacy of research participants. Ethical approval for this research study was granted by the University of Vermont Institutional Review Board protocol number CHRBSS:16-612.

\section{LITERATURE CITED}

Barnes, S., and J. Young. 2012. Cap-and-trade of diffuse emissions of nitrogen in Lake Taupo Catchment. Reviewing the policy decisions and the market. Technical Report No. 2013/34. Waikato Regional Council, Hamilton, New Zealand. 
Bay of Plenty Regional Council (BOPRC). 2016. Proposed Plan Change 10 (Lake Rotorua Nutrient Management). BOPRC, Whakantāne, New Zealand.

Bay of Plenty Regional Council (BOPRC). 2018. Operative Bay of Plenty Regional Natural Resources Plan. Ta Mahere Rawa Taiao a-Rohe. BOPRC, Whakantāne, New Zealand. [online] URL: https://www.boprc.govt.nz/your-council/plans-and-policies/ plans/regional/regional-natural-resources-plan/

Bay of Plenty Regional Council (BOPRC). 2020. Lake Rotorua Trophic level index long Term monitoring data [Personal communication with James Dare at BOPRC]. Used with permission by Bay of Plenty Regional Council.

Burns, N., J. McIntosh, and P. Scholes. 2009. Managing the lakes of the Rotorua district, New Zealand. Lake and Reservoir Management 25(3):284-296. https://doi.org/10.1080/07438140903083815

Carley, K., and M. Palmquist. 1992. Extracting, representing, and analyzing mental models. Social Forces 70(3):601-636. https://doi. org/10.2307/2579746

Carpenter, S. R., N. F. Caraco, D. L. Correll, R. W. Howarth, A. N. Sharpley, and V. H. Smith. 1998. Nonpoint pollution of surface waters with phosphorus and nitrogen. Ecological Applications 8 (3):559-568. https://doi.org/10.1890/1051-0761(1998)008[0559: NPOSWW]2.0.CO;2

Collins, K. M. T. 2010. Advanced sampling designs in mixed research. Chapter 15 in A. Tashakkori and C. Teddlie, editors. $S A G E$ handbook of mixed methods in social \& behavioral research. SAGE, Los Angeles, California, USA. https://dx.doi. org/10.4135/9781506335193.n15

Cox, M. 2014. Understanding large social-ecological systems: introducing the SESMAD project. International Journal of the Commons 8(2):265-276. https://doi.org/10.18352/ijc.406

Csardi, G., and T. Nepusz. 2006. The igraph software package for complex network research. InterJournal Complex Systems 1695.

DeCaro, D., and M. Stokes. 2013. Public participation and institutional fit: a social-psychological perspective. Ecology and Society 18(4):40. https://doi.org/10.5751/es-05837-180440

Delgado-Serrano, M. del M., and P. Ramos. 2015. Making Ostrom's framework applicable to characterise social ecological systems at the local level. International Journal of the Commons 9(2):808-830. https://doi.org/10.18352/ijc.567

Douglas, E. M., S. A. Wheeler, D. J. Smith, I. C. Overton, S. A. Gray, T. M. Doody, and N. D. Crossman. 2016. Using mentalmodelling to explore how irrigators in the Murray-Darling Basin make water-use decisions. Journal of Hydrology: Regional Studies 6:1-12. https://doi.org/10.1016/j.ejrh.2016.01.035

Ekstrom, J. A., and O. R. Young. 2009. Evaluating functional fit between a set of institutions and an ecosystem. Ecology and Society 14(2):16. https://doi.org/10.5751/ES-02930-140216

Flagg, K. 2015. Sacred cows: Does Vermont cut farmers too much slack on water quality violations? Seven Days, 1 April. [online] URL: https://www.sevendaysvt.com/vermont/sacred-cows-doesvermont-cut-farmers-too-much-slack-on-water-quality-violations/ Content?oid $=2546954$
Galaz, V., P. Olsson, T. Hahn, C. Folke, and U. Svedin. 2008. The problem of fit among biophysical systems, environmental and resource regimes, and broader governance systems: insights and emerging challenges. Pages 147-186 in O. R. Young, L. A. King, and $\mathrm{H}$. Schroeder, editors. Institutions and environmental change: principal findings, applications, and research frontiers. MIT Press, Cambridge, Massachusetts, USA. https://doi.org/10.7551/ mitpress/7920.003.0011

Goodin, R. E. 1998. The theory of institutional design. Cambridge University Press, Cambridge, UK. https://doi.org/10.1017/ CBO9780511558320

Hoffman, M., M. Lubell, and V. Hillis. 2014. Linking knowledge and action through mental models of sustainable agriculture. Proceedings of the National Academy of Sciences 111 (36):13016-13021. https://doi.org/10.1073/pnas.1400435111

Holland, P. 2015. The dirty dairying campaign and the clean streams accord. Lincoln Planning Review 6(1-2):63-69.

Hsieh, H.-F., and S. E. Shannon. 2005. Three approaches to qualitative content analysis. Qualitative Health Research 15 (9):1277-1288. https://doi.org/10.1177/1049732305276687

Jabbour, R., S. Zwickle, E. R. Gallandt, K. E. McPhee, R. S. Wilson, and D. Doohan. 2014. Mental models of organic weed management: comparison of New England U.S. farmer and expert models. Renewable Agriculture and Food Systems 29 (4):319-333. https://doi.org/10.1017/s1742170513000185

Jones, N., H. Ross, T. Lynam, P. Perez, and A. Leitch. 2011. Mental models: an interdisciplinary synthesis of theory and methods. Ecology and Society 16(1):46. https://doi.org/10.5751/ ES-03802-160146

Kerr, S., S. Greenhalgh, and G. Simmons. 2015. The Taupo nitrogen market: the world's only diffuse source trading programme. Motu Public Policy and Research, MOTU Note 20.

Lake Champlain Basin Program (LCBP). 2018. 2018 State of the lake and ecosystem indicators report. LCBP, Grand Isle, Vermont, USA.

Landcare Research New Zealand Ltd. 2015. LCDB v4.1-Land Cover Database version 4.1, Mainland New Zealand. Landcare Research New Zealand Ltd, Lincoln, New Zealand. https://doi. org/10.7931/L17H3

Leslie, H. M., X. Basurto, M. Nenadovic, L. Sievanen, K. C. Cavanaugh, J. J. Cota-Nieto, B. E. Erisman, E. Finkbeiner, G. Hinojosa-Arango, M. Moreno-Báez, et al. 2015. Operationalizing the social-ecological systems framework to assess sustainability. Proceedings of the National Academy of Sciences 112 (19):5979-5984. https://doi.org/10.1073/pnas.1414640112

Livestock Improvement Corporation (LIC) and DairyNZ. 2018. New Zealand Dairy Statistics 2017-18. Livestock Improvement Corporation Limited and DairyNZ Limited, Hamilton, New Zealand.

McDowell, R. W., R. M. Dils, A. L. Collins, K. A. Flahive, A. N. Sharpley, and J. Quinn. 2016. A review of the policies and implementation of practices to decrease water quality impairment by phosphorus in New Zealand, the UK, and the US. Nutrient 
Cycling in Agroecosystems 104(3):289-305. https://doi.org/10.1007/ s10705-015-9727-0

Mcdowell, R. W., S. T. Larned, and D. J. Houlbrooke. 2009. Nitrogen and phosphorus in New Zealand streams and rivers: control and impact of eutrophication and the influence of land management. New Zealand Journal of Marine and Freshwater Research 43(4):985-995. https://doi.org/10.1080/00288330909510055

McGinnis, M. D., and E. Ostrom. 2014. Social-ecological system framework: initial changes and continuing challenges. Ecology and Society 19(2):30. https://doi.org/10.5751/ES-06387-190230

Meals, D. W., S. A. Dressing, and T. E. Davenport, 2010. Lag time in water quality response to best management practices: a review. Journal of Environment Quality 39(1):85-96. https://doi. org/10.2134/jeq2009.0108

Ministry for the Environment (MftE). 2014. National Policy Statement for Freshwater Management 2014. New Zealand Gazette, No. 71, 1991-2017.

Multi-Resolution Land Characteristics Consortium. 2016. National Land Cover Database 2016. U.S. Geological Survey, Sioux Falls, South Dakota, USA. [online] URL: https://www. mrlc.gov/

North, D. C. 1990. Institutions, institutional change and economic performance. Cambridge University Press, Cambridge, UK. https://doi.org/10.1017/CBO9780511808678

Ostrom, E. 2005. Understanding institutional diversity. Princeton University Press, Princeton, New Jersey, USA.

Ostrom, E. 2009. A general framework for analyzing sustainability of social-ecological systems. Science 325 (5939):419-422. https://doi.org/10.1126/science.1172133

Pokorny, J. J., A. Norman, A. P. Zanesco, S. Bauer-Wu, B. K. Sahdra, and C. D. Saron. 2018. Network analysis for the visualization and analysis of qualitative data. Psychological Methods 23(1):169-183. https://doi.org/10.1037/met0000129

QSR International Pty Ltd. 2018. NVivo qualitative data analysis Software.

Quinn, J. M., R. J. Wilcock, R. M. Monaghan, R. W. McDowell, and P. Journeaux. 2009. Grassland farming and water quality in New Zealand. Tearmann: Irish Journal of AgriculturalEnvironmental Research 7:69-88.

R Core Team. 2018. R: A language and environment for statistical computing. R Foundation for Statistical Computing, Vienna, Austria.

Rissman, A. R., and S. R. Carpenter. 2015. Progress on nonpoint pollution: barriers \& opportunities. Daedalus 144(3):35-47. https://doi.org/10.1162/DAED_a_00340

Rotorua Te Arawa Lakes Programme. 2014. Lake Rotorua incentives scheme policy. Rotorua Te Arawa Lakes Programme, Rotorua, New Zealand.

Rutherford, J. C., R. D. Pridmore, and E. White. 1989. Management of phosphorus and nitrogen inputs to Lake Rotorua, New Zealand. Journal of Water Resources Planning and Management 115(4):431-439. https://doi.org/10.1061/(ASCE) 0733-9496(1989)115:4(431)
Saldaña, J. 2015. The coding manual for qualitative researchers. SAGE, London, UK.

Smeltzer, E. 2015. History of Vermont's Lake Champlain phosphorus reduction efforts. Vermont Journal of Environmental Law 17:615.

Smeltzer, E., A. D. Shambaugh, and P. Stangel, 2012. Environmental change in Lake Champlain revealed by long-term monitoring. Journal of Great Lakes Research 38(Supplement 1):6-18. https://doi.org/10.1016/j.jglr.2012.01.002

Smith, J. M., R. L. Parsons, K. Van Dis, and G. N. Matiru. 2008. Love thy neighbor-but does that include a six hundred eightyfour cow dairy operation? A survey of community perceptions. Journal of Dairy Science 91(4):1673-1685. https://doi. org/10.3168/jds.2007-0702

The Rotorua Lakes Protection and Restoration Action Programme. 2009. Lakes Rotorua and Rotoiti Action Plan. Environment Bay of Plenty, Whakatāne, New Zealand.

University of Vermont Spatial Analysis Laboratory. 2019. LandLandcov_BaseLC2016, remote-sensing image.. Vermont Center for Geographic Information, Montpelier, Vermont, USA.

U.S. Census Bureau. 2010. Census of population and housing. U. S. Census Bureau, Washington, D.C., USA.

U.S. Department of Agriculture National Agricultural Statistics Service (USDA-NASS). 2017. Census of Agriculture, State and County Reports (Vermont). USDA-NASS, Washington, D.C., USA.

U.S. Environmental Protection Agency (USEPA). 2016. Phosphorus TMDLs for Vermont Segments of Lake Champlain. USEPA, Washington, D.C., USA.

Vatn, A., and P. Vedeld. 2012. Fit, interplay, and scale: a diagnosis. Ecology and Society 17(4):12. https://doi.org/10.5751/ES-05022-170412

Verburg, P., and A. Albert. 2019. Lake Taupo long-termmonitoring programme 2017-2018 Technical Report 2019/18 Document \#:14572688. Waikato Regional Council, Hamilton, New Zealand.

Vermont Agency of Agriculture, Food \& Markets (VAAFM). 2018. Vermont required agricultural practices rule for the agricultural nonpoint source pollution control program. VAAFM, Montpelier, Vermont, USA.

Vermont Agency of Agriculture, Food \& Markets (VAAFM). [date unknown]. Farm size classifications. VAAFM, Montpelier, Vermont, USA.

Vermont Dairy Production Council (VDPC). 2015. Milk matters: the role of dairy in Vermont: an economic assessment. VDPC, Richford, Vermont, USA.

Vermont Department of Environmental Conservation. 2020. Lake Champlain long-term monitoring. Vermont Department of Environmental Conservation, Montpelier, Vermont. [online] URL: https://anrweb.vermont.gov/dec/_dec/LongTermMonitoringLakes. $\underline{\text { aspx }}$

Vermont General Assembly (VGA). 2015. Act 64: An Act Relating to Improving the Quality of State Waters. State of Vermont, Montpelier, Vermont, USA. 
Waikato Regional Council (WRC). 2011a. Variation 5 - Lake Taupo Catchment Operative Version. Waikato Regional Council, Hamilton, New Zealand.

Waikato Regional Council (WRC). 2011b. Nitrogen management in the Lake Taupo catchment: an overview of Waikato Regional Plan Variation 5 requirements. Waikato Regional Council, Hamilton, New Zealand.

Wironen, M. B., E. M. Bennett, and J. D. Erickson. 2018. Phosphorus flows and legacy accumulation in an animaldominated agricultural region from 1925 to 2012. Global Environmental Change 50:88-99. https://doi.org/10.1016/j. gloenvcha.2018.02.017

Young, O. R., L. A. King, and H. Schroeder. 2008. Institutions and environmental change: principal findings, applications, and research frontiers. MIT Press Cambridge, Massachusetts, USA. https://doi.org/10.7551/mitpress/9780262240574.001.0001

Zia, A., and A. M. Todd. 2010. Evaluating the effects of ideology on public understanding of climate change science: how to improve communication across ideological divides? Public Understanding of Science 19(6):743-761. https://doi. org/10.1177/0963662509357871 


\section{Appendix 1}

Table A1.1. Interview protocol question for farmers

\begin{tabular}{l} 
Interview protocol questions \\
How long have you or your family been farming in the watershed? \\
Could you tell me a bit about your farm system? \\
Can you run me through what a week on your farm looks like? \\
In the last 5-10 years, have you made any changes to your farm system or the \\
management of your farm business? What was the driver for these changes? \\
What are the costs of these changes? Benefits? \\
Are you planning to make any changes to your farm system in the next 2 years? \\
Can you tell me a little about your experience with the water quality policy \\
process? \\
Has the capping of nutrients changed the face of the watershed? \\
How fair do you think the policy is/was? \\
Would you have done anything different to manage water quality in the lake? \\
\hline \hline
\end{tabular}

Table A1.2. Full codebook with descriptions and representative quotes

\begin{tabular}{|l|l|l|}
\hline Nodes & Description & Example Quote \\
\hline drivers & & \\
\hline Actor & $\begin{array}{l}\text { funding, debt, efficiency, } \\
\text { other sources of income, } \\
\text { dependence on farm }\end{array}$ & $\begin{array}{l}\text { "I think, ultimately, its profitability. } \\
\text { The most decisions we've made are } \\
\text { on profitability. And so, the smaller, } \\
\text { environmental changes - well, } \\
\text { there's benefits as well. So, applying } \\
\text { nutrients on lower rates more often, } \\
\text { if we don't waste the nutrients, it } \\
\text { makes more sense. So, most of those } \\
\text { changes, we hope, eventually, help } \\
\text { profitability as well." }\end{array}$ \\
\hline A_ethic & $\begin{array}{l}\text { stewardship or land ethic, love } \\
\text { of learning, aesthetic, price of } \\
\text { being a "good farmer" }\end{array}$ & $\begin{array}{l}\text { "And we did a lot of those things } \\
\text { because we were under a lot of } \\
\text { pressure. But that's not the whole } \\
\text { story. We are an environmental } \\
\text { organization. So, it's sort of part of } \\
\text { our mission to be good. So, it wasn't } \\
\text { like we didn't want to do them. It's } \\
\text { what we're supposed to do." }\end{array}$ \\
\hline
\end{tabular}




\begin{tabular}{|c|c|c|}
\hline A_flexibility & $\begin{array}{l}\text { convenience, steady supply, } \\
\text { lifestyle, flexibility in running } \\
\text { the farm system }\end{array}$ & $\begin{array}{l}\text { "Yeah it was about giving us more } \\
\text { flexibility in our system, and to help } \\
\text { try and drought proof, yeah to - for } \\
\text { the lake issue was, it was about } \\
\text { being capped, effectively capped. } \\
\text { That is a way of still being able to } \\
\text { improve and maximize. But it also } \\
\text { gave us another block of land that is } \\
\text { separate if we ever wanted to sell } \\
\text { something or anything like that." }\end{array}$ \\
\hline $\begin{array}{l}\text { A_leadership or } \\
\text { entrepreneur }\end{array}$ & $\begin{array}{l}\text { Actor themselves represented } \\
\text { leadership and } \\
\text { entrepreneurial spirit to drive } \\
\text { change, or actor received } \\
\text { advice or followed path of } \\
\text { leader or entrepreneur. For } \\
\text { personal, the actor should } \\
\text { mention something about } \\
\text { trying something new, being } \\
\text { on the cutting edge, taking a } \\
\text { risk, taking leadership or being } \\
\text { an entrepreneur. For receiving } \\
\text { advice, the actor should } \\
\text { mention a figure or figures } \\
\text { that influenced their change. }\end{array}$ & $\begin{array}{l}\text { "Two and a half years ago we made } \\
\text { the decision that we were sick of } \\
\text { dealing with dairy farmers, and that } \\
\text { we were really really keen to } \\
\text { support [a new business initiative } \\
\text { led by local farmers]. So we went } \\
\text { and saw them to see what they } \\
\text { needed and how it would work." }\end{array}$ \\
\hline A_lifestyle & $\begin{array}{l}\text { this includes ease of } \\
\text { management }\end{array}$ & $\begin{array}{l}\text { "So really I make the decision based } \\
\text { on what I want to do, what I think is } \\
\text { going to be more profitable, what } \\
\text { suits the way I farm as well and my } \\
\text { lifestyle." }\end{array}$ \\
\hline A_past experience & $\begin{array}{l}\text { past experience with } \\
\text { policy/state/regional } \\
\text { government }\end{array}$ & $\begin{array}{l}\text { "So the decision had been made by } \\
\text { then that they were going to } \\
\text { benchmark and that we knew. So I } \\
\text { knew how the farming system was } \\
\text { going to work [because of } \\
\text { experience with the policy process } \\
\text { and previously owning land in the } \\
\text { catchment]. I probably knew it } \\
\text { better than anybody, I'd say. So } \\
\text { that's why I was more comfortable } \\
\text { in getting back in." }\end{array}$ \\
\hline
\end{tabular}




\begin{tabular}{|c|c|c|}
\hline A_social attributes & family life, succession & $\begin{array}{l}\text { "Well, I had a son and daughter } \\
\text { both milking cows for someone else } \\
\text { and then would come home and } \\
\text { crutch lambs. So, I was left in the } \\
\text { muck and getting no time off } \\
\text { because there's only one main unit. } \\
\text { And so, we thought if we could buy } \\
\text { the dairy unit, we'd employ more } \\
\text { staff and hopefully be able to get on } \\
\text { the roster and get some time off." } \\
\text { "No incentive and stuff, but the } \\
\text { other thing with the lake is it's the } \\
\text { taonga for the Maori. So it's their } \\
\text { treasure. They were very keen to } \\
\text { protect it anyway, and they'd made } \\
\text { decisions around the lake to protect } \\
\text { it way before Environment Waikato } \\
\text { started." }\end{array}$ \\
\hline A_technology & $\begin{array}{l}\text { availability of specific } \\
\text { technology }\end{array}$ & $\begin{array}{l}\text { "We've modeled land use change [to } \\
\text { make a farm diversification plan]." }\end{array}$ \\
\hline \multicolumn{3}{|l|}{ Governance } \\
\hline G_gov assistance & $\begin{array}{l}\text { technical or financial } \\
\text { assistance from a government } \\
\text { agency }\end{array}$ & $\begin{array}{l}\text { "The guy I've been working with } \\
\text { through NRCS, he keeps me pretty } \\
\text { informed. I'm pretty good friends } \\
\text { with him, so he keeps me quite } \\
\text { informed on everything and we go } \\
\text { over stuff. I had a couple spots that I } \\
\text { had to change things but other than } \\
\text { that we've been pretty - we pretty } \\
\text { much knew what was going on." }\end{array}$ \\
\hline G_ngos or other & $\begin{array}{l}\text { Interactions with non- } \\
\text { governmental entities, these } \\
\text { include organic, extension, } \\
\text { watershed programs, land } \\
\text { trusts, housing and } \\
\text { conservation board, industry } \\
\text { group requirements or best } \\
\text { practices, and research } \\
\text { organizations/universities }\end{array}$ & $\begin{array}{l}\text { "As far as the rules for organic are } \\
\text { so strict that these new laws on the } \\
\text { water quality and watershed, we've } \\
\text { already been having to follow since } \\
\text { we went organic. The stream } \\
\text { setbacks and all that are already in } \\
\text { there for organic." }\end{array}$ \\
\hline G_other gov policies & $\begin{array}{l}\text { Central, regional or local } \\
\text { government policies that } \\
\text { impact nutrient management, } \\
\text { such as conservation policies }\end{array}$ & $\begin{array}{l}\text { "Well, we were up for resource } \\
\text { consent, so it was - as far as the } \\
\text { effluent upgrade, it helped us get a } \\
\text { longer resource consent, and it kept } \\
\text { us compliant." }\end{array}$ \\
\hline
\end{tabular}




\begin{tabular}{|c|c|c|}
\hline G_farmer group & $\begin{array}{l}\text { participation in a group } \\
\text { representing farmer interests }\end{array}$ & $\begin{array}{l}\text { "I probably got a little bit involved in } \\
\text { [the farmer group] as to see how } \\
\text { [the policy] was going to work more } \\
\text { for my own selfish reasons because } \\
\text { most of the farms around here are } \\
\text { managed by farm managers, and I } \\
\text { thought well if it's going to turn to } \\
\text { shit I'd really want to be the first one } \\
\text { to get out but if I could see some } \\
\text { opportunities I wanted to stay" }\end{array}$ \\
\hline G_water quality policy & cap, state, regional policy & $\begin{array}{l}\text { "And the interesting thing was that } \\
\text { when they brought the new rules } \\
\text { into the catchment, the big } \\
\text { businesses that owned those farms, } \\
\text { sold the farms in the catchment } \\
\text { straight away." } \\
\text { "Some fields flood. Some of my land, } \\
\text { I'm on the early spreading ban. Do } \\
\text { with the new [water quality policy]. I } \\
\text { got to hit them in the midsummer, } \\
\text { so we're changing the way we got to } \\
\text { do things, a little bit. We'll see in a } \\
\text { few years. Hopefully, it'll benefit." }\end{array}$ \\
\hline \multicolumn{3}{|l|}{ Resource_system } \\
\hline RS_ecological & $\begin{array}{l}\text { erosion, runoff, endowment, } \\
\text { improve ecosystem, nutrients, } \\
\text { drought, flooding }\end{array}$ & $\begin{array}{l}\text { "I bought a manure truck, so I had to } \\
\text { do it myself, now... Well, doing it } \\
\text { myself, I'll do it more times per year, } \\
\text { less each time, and try to minimalize } \\
\text { runoff and get on when the land } \\
\text { needs it. When the land can use it." }\end{array}$ \\
\hline RS_farm production & $\begin{array}{l}\text { animal needs, } \\
\text { increase/decrease, quality of } \\
\text { product, pasture integrity }\end{array}$ & $\begin{array}{l}\text { "Originally the country that went } \\
\text { into pines was the lower producing } \\
\text { areas, but the nitrogen is sort of } \\
\text { considered to be across the whole } \\
\text { farm. So by taking out the lower } \\
\text { producing areas it meant we could } \\
\text { farm the better areas a little bit } \\
\text { more intensively which gave us } \\
\text { options, but then they sold more } \\
\text { nitrogen and now we don't have a } \\
\text { lot of options." }\end{array}$ \\
\hline \multicolumn{3}{|l|}{ Resource_units } \\
\hline RU_n $p$ attributes & $\begin{array}{l}\text { attributes of } \mathrm{N} \& \mathrm{P} \text { and the } \\
\text { movement of these nutrients } \\
\text { in the landscape and farm } \\
\text { system }\end{array}$ & $\begin{array}{l}\text { "I'm doing it as a cover crop and I'm } \\
\text { gonna crop it. I'm gonna do it as a } \\
\text { forage so we're gonna chop it. } \\
\text { We're gonna try it because the soil } \\
\text { will pull up a lot of phosphorus out } \\
\text { of the soil. Really, every time you } \\
\text { plow and see the field, you're } \\
\text { releasing that phosphorus that's }\end{array}$ \\
\hline
\end{tabular}




\begin{tabular}{|c|c|c|}
\hline & & $\begin{array}{l}\text { bound because phosphorus doesn't } \\
\text { move in the soil. " }\end{array}$ \\
\hline \multicolumn{3}{|l|}{$\begin{array}{l}\text { Social economic and } \\
\text { political settings }\end{array}$} \\
\hline S_industry or consultant & & $\begin{array}{l}\text { "So, we actually did a feasibility } \\
\text { study. We got consultants to do a } \\
\text { feasibility study, put the whole thing } \\
\text { together, talked to the accountant, } \\
\text { and then went to the bank and the } \\
\text { regional council on the condition } \\
\text { that - the last condition for doing it } \\
\text { for buying the farm was that the } \\
\text { pond was that we got the consent } \\
\text { for the whole thing." }\end{array}$ \\
\hline S_c market & Carbon Market as a driver & $\begin{array}{l}\text { "[Did you get carbon credits on } \\
\text { that?] On the pines that they } \\
\text { planted yes... So when [the farm] } \\
\text { sold the nitrogen, Mighty River } \\
\text { Power generate energy out of the } \\
\text { lake. They've got the dams in the } \\
\text { river. So they put a deal that they } \\
\text { wanted carbon so they tied the two } \\
\text { together." }\end{array}$ \\
\hline S_demographic shifts & $\begin{array}{l}\text { For example, people going out } \\
\text { of farming without a } \\
\text { successor }\end{array}$ & $\begin{array}{l}\text { "I was renting these places - I had } \\
\text { my milkers - and, I was renting } \\
\text { places for my heifers. And, I had my } \\
\text { heifers over at this farm, over here. } \\
\text { This [neighbor 1] - that I told you he } \\
\text { only milked } 35 \text { cows - he had sold } \\
\text { his cows; he had retired from } \\
\text { farming. And, I had my heifers way } \\
\text { over at [neighbor 2's], at a different } \\
\text { farm. And, [neighbor 2] came to me, } \\
\text { and said, "Do you want to rent my } \\
\text { pastures?" And so, I rented them, } \\
\text { and it was a lot of fence, because it } \\
\text { was a hexagon, so it was a big } \\
\text { area." }\end{array}$ \\
\hline $\begin{array}{l}\text { S_economics and } \\
\text { markets }\end{array}$ & $\begin{array}{l}\text { competition, profit, efficiency, } \\
\text { prices broader than the } \\
\text { watershed dynamic, carbon } \\
\text { credit opportunities }\end{array}$ & $\begin{array}{l}\text { "The main reason why we came } \\
\text { back in and bought here was } \\
\text { location. Secondly, different land } \\
\text { use in the future. And thirdly, land } \\
\text { prices. Land prices had dropped by } \\
\text { thirty or forty percent, so it made it } \\
\text { economic to get back in again." }\end{array}$ \\
\hline
\end{tabular}




\begin{tabular}{|c|c|c|}
\hline S_n market & Nitrogen market as a driver & $\begin{array}{l}\text { "We planted about } 40 \text { hectares of } \\
\text { pine trees, production pines, but no, } \\
\text { the size didn't change at all. And } \\
\text { that was partly because we'd sold } \\
\text { some nitrate credits, once we got } \\
\text { our cap sorted out, we had plenty so } \\
\text { we sold it down." }\end{array}$ \\
\hline S_social context & Neighbor complaints & $\begin{array}{l}\text { "I tell my friend, I said "Farming is a } \\
\text { hostile environment right now. It's } \\
\text { hostile." I mean, the environment } \\
\text { that we're in is hostile. Not only do } \\
\text { we have pressure from regulators, } \\
\text { we have regulations, we have } \\
\text { pressure from intolerance from the } \\
\text { community." }\end{array}$ \\
\hline \multicolumn{3}{|l|}{ outcomes } \\
\hline \multicolumn{3}{|l|}{ Individual Outcomes } \\
\hline \multicolumn{3}{|l|}{ IO_negative economic } \\
\hline IO_Neg_compliance & $\begin{array}{l}\text { compliance costs related to } \\
\text { policy }\end{array}$ & $\begin{array}{l}\text { "But it's just got to the point where I } \\
\text { might actually have to get a little bit } \\
\text { more involved with it, because they } \\
\text { just sent me a monitoring bill that } \\
\text { was huge and I've just wrote a letter } \\
\text { to them and said that l'm not going } \\
\text { to pay that because that's } 153 \\
\text { percent increase on last year's bill." }\end{array}$ \\
\hline IO_Neg_farm viability & $\begin{array}{l}\text { Reduction in ability for farm to } \\
\text { remain solvent and profitable, } \\
\text { survive as a business }\end{array}$ & $\begin{array}{l}\text { "Well, just for the very reason - if } \\
\text { you can't grow your business then } \\
\text { you can't survive. So, we had to } \\
\text { shift. So, we decided we would } \\
\text { reduce our operation in the } \\
\text { catchment, and increase our } \\
\text { operation outside of the } \\
\text { catchment." }\end{array}$ \\
\hline IO_Neg_financial & $\begin{array}{l}\text { Reduction in profit, payoff, } \\
\text { funding, reduced earnings, } \\
\text { compliance, property value, } \\
\text { new revenue streams } \\
\text { including new products, new } \\
\text { markets, diversification }\end{array}$ & $\begin{array}{l}\text { "Well, there are direct financial } \\
\text { costs and there are also social costs, } \\
\text { I think. The direct cost to you is } \\
\text { these physical costs like building } \\
\text { detainment berms and putting } \\
\text { effluent ponds and buying upgraded } \\
\text { irrigators and things like that." }\end{array}$ \\
\hline
\end{tabular}




\begin{tabular}{|c|c|c|}
\hline IO_Neg_flexibility & $\begin{array}{l}\text { Loss of flexibility in farm } \\
\text { management }\end{array}$ & $\begin{array}{l}\text { "And before the rules, you could do } \\
\text { whatever you wanted to do. Now, } \\
\text { you can probably make changes as } \\
\text { long as you stay within the rules. So, } \\
\text { I suppose, yes. We started cropping } \\
\text { in the summer to develop those } \\
\text { pellets to improve the quality of } \\
\text { grass. And that's not going to } \\
\text { happen. So, that hasn't changed in a } \\
\text { way. Although, I don't know think } \\
\text { we expected to do it for long } \\
\text { anyway, did we? It's just an option } \\
\text { that we don't have anymore." }\end{array}$ \\
\hline \multicolumn{3}{|l|}{ IO_negative social } \\
\hline $\begin{array}{l}\text { IO_Neg_distrust in } \\
\text { regulation }\end{array}$ & $\begin{array}{l}\text { Frustration or distrust with } \\
\text { regulation or agency } \\
\text { implementing the regulation, } \\
\text { or in the monitoring } \\
\text { (Overseer) }\end{array}$ & $\begin{array}{l}\text { "Oh, I just don't contact [the } \\
\text { Regional Council]. Because I don't } \\
\text { have enough respect or trust in } \\
\text { them to be able to do that." }\end{array}$ \\
\hline IO_Neg_fairness & $\begin{array}{l}\text { Perceived that situation is } \\
\text { unfair in individual position }\end{array}$ & $\begin{array}{l}\text { "We planted trees on steep land to } \\
\text { stop erosion. And we did flood } \\
\text { control work. And I can show you } \\
\text { that on the photos that I've got. And } \\
\text { those things all worked really well, } \\
\text { but the annoying thing is that now } \\
\text { that doesn't count towards what } \\
\text { we're doing. So, what we've done is, } \\
\text { we've harvested the trees, and we } \\
\text { haven't replanted. Because we need } \\
\text { to have more grass to try and keep } \\
\text { our cow numbers up. It's stupid. It's } \\
\text { stupid that they're not recognizing } \\
\text { environmental benefits that were } \\
\text { done in the '90s and the '80s." }\end{array}$ \\
\hline $\begin{array}{l}\text { IO_Neg_non-financial } \\
\text { costs }\end{array}$ & $\begin{array}{l}\text { time, depression, involvement } \\
\text { with community }\end{array}$ & $\begin{array}{l}\text { "It was tough, man it was tough. } \\
\text { Because we were all farming. We } \\
\text { used to joke and say man this would } \\
\text { be great if this was your day job. } \\
\text { Because A) you are on a salary, B) } \\
\text { You are really interested, C) you } \\
\text { haven't got any skin in the game, } \\
\text { and it's just really interesting stuff. } \\
\text { But we were all trying to hold down, } \\
\text { I had two little babies, trying to hold } \\
\text { down farms, and businesses, and } \\
\text { represent people and communicate } \\
\text { and try and forge our way through } \\
\text { this process, it was incredibly hard." }\end{array}$ \\
\hline
\end{tabular}




\begin{tabular}{|c|c|c|}
\hline $\begin{array}{l}\text { IO_Neg_uncertainty in } \\
\text { future }\end{array}$ & $\begin{array}{l}\text { Uncertainty in the future of } \\
\text { the farm system and what will } \\
\text { be possible }\end{array}$ & $\begin{array}{l}\text { "Well, we won't have a business. } \\
\text { Because they're looking for a } 30 \\
\text { percent reduction. So, instead of } \\
\text { having } 230 \text { cows, we'll have } 160 \\
\text { cows. That just won't work. Just like } \\
\text { if you're salary got cut by a third, it } \\
\text { would certainly change your } \\
\text { perspective as well." }\end{array}$ \\
\hline \multicolumn{3}{|l|}{ IO_neutral economic } \\
\hline IO_Neu_compliance & $\begin{array}{l}\text { Compliance with policy is a } \\
\text { negligible cost }\end{array}$ & $\begin{array}{l}\text { "So, you know I mean the RAPs I } \\
\text { mean definitely yes we've had to } \\
\text { make some adaptations to our } \\
\text { management here and all, but they } \\
\text { haven't really impacted us } \\
\text { detrimentally. It hasn't been a big } \\
\text { burden or impact on us as a farm." }\end{array}$ \\
\hline \multicolumn{3}{|l|}{ IO_positive ecological } \\
\hline $\begin{array}{l}\text { IO_Pos_environmental } \\
\text { quality }\end{array}$ & specific resource not specified & $\begin{array}{l}\text { "No. No benefits. Apart from } \\
\text { environmental benefits, that's about } \\
\text { it. Certainly no financial benefits." }\end{array}$ \\
\hline IO_Pos_soil quality & $\begin{array}{l}\text { improvements in individual's } \\
\text { soil and pasture quality }\end{array}$ & $\begin{array}{l}\text { "And all that where the brook is, it's } \\
\text { not mud now, its grass. And going } \\
\text { over the years, it's not just grass, it's } \\
\text { nice grass - nice, and lush grass; } \\
\text { and, I only pasture it, maybe, three } \\
\text { or four times a year." }\end{array}$ \\
\hline IO_Pos_water quality & $\begin{array}{l}\text { improvements in water } \\
\text { quality at the farm-scale level, } \\
\text { or due to farm-scale level } \\
\text { behaviors }\end{array}$ & $\begin{array}{l}\text { "So, I think we must - so, if water } \\
\text { quality is improving in [the] Bay... } \\
\text { Something is happening. Some of } \\
\text { these practices are - and I don't } \\
\text { know whether that has to do with it } \\
\text { or not. I just think we've done so } \\
\text { much - that it's useful. It's proven } \\
\text { that it works." }\end{array}$ \\
\hline IO_positive economic & & $\begin{array}{l}\text { "Yeah, so that's what I'm trying to } \\
\text { say. If I'd kept running a similar } \\
\text { number of stock my nitrogen output } \\
\text { would have dropped but the policy } \\
\text { changes allowed me to improve the } \\
\text { farm's productivity without } \\
\text { breaching my nitrogen cap." }\end{array}$ \\
\hline IO_Pos_farm viability & $\begin{array}{l}\text { improvements in ability for } \\
\text { farm to remain solvent and } \\
\text { profitable, survive as a } \\
\text { business }\end{array}$ & $\begin{array}{l}\text { "Well, the NMP plan is a chance to } \\
\text { save money, there, because we } \\
\text { know for over fertilizing. With the } \\
\text { first one we did, the comprehensive } \\
\text { one, we found out that we were } \\
\text { putting almost double manure on } \\
\text { the grassland than we should've } \\
\text { been. You can put too much. It's all } \\
\text { there is to it. You put too much. } \\
\text { That's a good thing to save money, } \\
\text { if you can." }\end{array}$ \\
\hline
\end{tabular}




\begin{tabular}{|c|c|c|}
\hline IO_Pos_financial & $\begin{array}{l}\text { Improvement in profit, payoff, } \\
\text { funding, increased earnings, } \\
\text { compliance, property value, } \\
\text { new revenue streams } \\
\text { including new products, new } \\
\text { markets, diversification }\end{array}$ & $\begin{array}{l}\text { "Yeah there were benefits. For } \\
\text { people like me that had very, very } \\
\text { high NDAs, to have sold a few off } \\
\text { the top. Like I sold down to a } \\
\text { reasonable level and that would } \\
\text { have been good if we hadn't lost the } \\
\text { extra } 1300 \text {. So there were benefits in } \\
\text { yeah any very, very high NDA farms } \\
\text { - could get part of their capital out. } \\
\text { It was like selling part of your farm, } \\
\text { but actually not losing the farm." }\end{array}$ \\
\hline IO_Pos_flexibility & $\begin{array}{l}\text { Improvement in flexibility in } \\
\text { farm management }\end{array}$ & $\begin{array}{l}\text { "Pretty much, like we sold down the } \\
\text { cattle and replaced those cows with } \\
\text { trading stock and they were winter } \\
\text { grazers, so it didn't really alter the } \\
\text { figure too much, it just gave us more } \\
\text { management flexibility." }\end{array}$ \\
\hline IO_Pos_new markets & $\begin{array}{l}\text { Accessing new markets, } \\
\text { marketing, pricing, supply } \\
\text { chain changes }\end{array}$ & $\begin{array}{l}\text { "We're certainly producing the } \\
\text { product, but we haven't had a } \\
\text { decent product to sell, which has } \\
\text { been the biggest issue. We've tried } \\
\text { cheese and yoghurts. We have been } \\
\text { exporting frozen milk to our cheese } \\
\text { maker in Aussie for the last few } \\
\text { years. But the last } 18 \text { months we've } \\
\text { taken on a [new] partner and } \\
\text { they're powdering it and take it to } \\
\text { China. That's been a pretty amazing } \\
\text { leap forward, and it's given us a } \\
\text { solid market with reasonable } \\
\text { returns." }\end{array}$ \\
\hline \multicolumn{3}{|l|}{ IO_positive social } \\
\hline IO_Pos_awareness & $\begin{array}{l}\text { improved understanding of } \\
\text { farm system, nutrient } \\
\text { dynamics }\end{array}$ & $\begin{array}{l}\text { "So those sort of things, yeah, you're } \\
\text { very aware of - we talk a whole new } \\
\text { language now in terms of nitrogen } \\
\text { discharge allowance, NDAs and } \\
\text { things like that. Yeah and we're } \\
\text { conscious of those things. We live in } \\
\text { a different world here now." }\end{array}$ \\
\hline $\begin{array}{l}\text { IO_Pos_non-financial } \\
\text { benefits }\end{array}$ & $\begin{array}{l}\text { new opportunities, } \\
\text { involvement with community, } \\
\text { sense of pride in work, } \\
\text { reduces burden of work }\end{array}$ & $\begin{array}{l}\text { "Oh, I sleep easier at night. Yeah, to } \\
\text { keep compliant with the old pond, I } \\
\text { did some stuff that I wasn't very } \\
\text { proud of. But he had to do it to stay } \\
\text { compliant really. Yeah, so now all } \\
\text { that's gone now. Easier } \\
\text { management and all that sort of } \\
\text { stuff is, yeah." }\end{array}$ \\
\hline
\end{tabular}




\begin{tabular}{|c|c|c|}
\hline $\begin{array}{l}\text { IO_Pos_enviro } \\
\text { recognition }\end{array}$ & $\begin{array}{l}\text { Received recognition for } \\
\text { environmental } \\
\text { stewardship/sustainability of } \\
\text { farm system }\end{array}$ & $\begin{array}{l}\text { "Then we won the [environmental } \\
\text { award], now is the moment when } \\
\text { the dollars profit per KG of nitrogen } \\
\text { came together. We've been testing, } \\
\text { the [farm system] thing is just a big } \\
\text { experiment. We've measured } \\
\text { ourselves against other farmers } \\
\text { through the [award]." }\end{array}$ \\
\hline \multicolumn{3}{|l|}{ watershed outcomes } \\
\hline \multicolumn{3}{|l|}{ WO_negative ecological } \\
\hline $\begin{array}{l}\text { WO_Neg_environmental } \\
\text { quality }\end{array}$ & specific resource not specified & $\begin{array}{l}\text { "Well, we're back again to the } \\
\text { nitrogen, phosphorus/biodiversity. } \\
\text { Because if you look at what the } \\
\text { Regional Council's job is, it's not only } \\
\text { nutrients, its biodiversity. It's } \\
\text { protecting native bush. Its pests. } \\
\text { There are a lot of things. But it's only } \\
\text { actually PC } 10 \text { hasn't taken into } \\
\text { consideration any of those other } \\
\text { things that actually the Regional } \\
\text { Council is in charge of implementing, } \\
\text { or controlling." }\end{array}$ \\
\hline $\begin{array}{l}\text { WO_Neg_land use } \\
\text { patterns }\end{array}$ & & $\begin{array}{l}\text { "That was all taken out of farm land } \\
\text { and they were farming } \\
\text { conservatively anyway. They were } \\
\text { having no effect on the lake over } \\
\text { there at all because they all had } \\
\text { sheep. But that's all in trees now." }\end{array}$ \\
\hline WO_Neg_water quality & & $\begin{array}{l}\text { "So this trading of nitrogen also } \\
\text { creates another problem of what } \\
\text { they call hotspots. Some people } \\
\text { don't want to know about it but of } \\
\text { course it makes a difference. Put it } \\
\text { this way; if I put this tea towel on } \\
\text { the bench and I get two glasses of } \\
\text { water, one I just sprinkle lightly } \\
\text { everywhere, it hardly sinks through, } \\
\text { the other one I just pour it right } \\
\text { here, you're going to find a big } \\
\text { puddle here that's going to run over } \\
\text { here. In effect this nitrogen cap } \\
\text { thing has done exactly that." }\end{array}$ \\
\hline WO_negative economic & & \\
\hline
\end{tabular}




\begin{tabular}{|c|c|c|}
\hline $\begin{array}{l}\text { WO_Neg_farming } \\
\text { viability }\end{array}$ & $\begin{array}{l}\text { Reduction in ability for } \\
\text { farming in the watershed to } \\
\text { remain solvent and profitable, } \\
\text { survive as a business/industry }\end{array}$ & $\begin{array}{l}\text { "That's just what happens. The - } \\
\text { yeah, they're a lot of farms that are } \\
\text { - it's kind of a perfect storm } \\
\text { situation too, where I think the } \\
\text { number of farms is like } 750 \text { farms } \\
\text { left in the state... Somebody said the } \\
\text { other day that they read from the } \\
\text { agency that they could see } 150 \text { to } \\
200 \text { more farms go out this year. A } \\
\text { lot of that's like - milk price, and } \\
\text { then regulations at the same time." }\end{array}$ \\
\hline $\begin{array}{l}\text { WO_Neg_financial } \\
\text { watershed }\end{array}$ & $\begin{array}{l}\text { profit, payoff, funding, } \\
\text { reduced earnings, compliance, } \\
\text { property value, new revenue } \\
\text { streams including new } \\
\text { products, new markets, } \\
\text { diversification }\end{array}$ & $\begin{array}{l}\text { "Farmers have made a real stand in } \\
\text { this catchment to say, 'We can do } \\
\text { this, what's required by 2022, } \\
\text { whatever the percentage top is. But } \\
\text { what's required after } 2032 \text { is not } \\
\text { doable. Financially, it's not doable."' }\end{array}$ \\
\hline \multicolumn{3}{|l|}{ WO_negative social } \\
\hline WO_Neg_well-being & $\begin{array}{l}\text { community involvement, } \\
\text { depression, community } \\
\text { members leaving }\end{array}$ & $\begin{array}{l}\text { "So, I think - but it's like grievance; } \\
\text { this - this phase is the angry phase, } \\
\text { and then acceptance might come } \\
\text { because that's what happened for } \\
\text { us in the Taupo catchment like I } \\
\text { say." }\end{array}$ \\
\hline WO_Neg_fairness & $\begin{array}{l}\text { perceived fairness of the } \\
\text { policy process/policy } \\
\text { outcomes }\end{array}$ & $\begin{array}{l}\text { "When grandparenting was on the } \\
\text { table, who was going to miss out? } \\
\text { [Maori land], big time. And as } \\
\text { owners of the lakebed, and } \\
\text { individually owners of the farms, a } \\
\text { lot of farms especially down in the } \\
\text { Western area, 55\% of the } \\
\text { landholding, they had a really big } \\
\text { series of interests to try and weigh } \\
\text { up. And they had voluntarily retired } \\
\text { a whole heap of their own land... } \\
\text { And so when grandparenting came } \\
\text { out, these guys were severely } \\
\text { penalized. There is no recognition } \\
\text { of those environmental benefits } \\
\text { from having already given. So you } \\
\text { can understand why they are pretty } \\
\text { pissed off." }\end{array}$ \\
\hline \multicolumn{3}{|l|}{ WO_neutral ecological } \\
\hline $\begin{array}{l}\text { WO_Neu_lack of } \\
\text { changes }\end{array}$ & $\begin{array}{l}\text { Not sure whether there is a } \\
\text { positive or negative impact on } \\
\text { water quality or other } \\
\text { environmental indicators at } \\
\text { the watershed scale }\end{array}$ & $\begin{array}{l}\text { "The land use, land use change, in } \\
\text { the catchment, has been minor." }\end{array}$ \\
\hline WO_neutral economic & & \\
\hline
\end{tabular}




\begin{tabular}{|c|c|c|}
\hline $\begin{array}{l}\text { WO_Neu_economic } \\
\text { impact }\end{array}$ & $\begin{array}{l}\text { Perception that policy has had } \\
\text { neutral economic impacts }\end{array}$ & $\begin{array}{l}\text { "But actually, well, I've personally } \\
\text { found it pretty easy, it hasn't been } \\
\text { too bad at all. Most of the farms } \\
\text { down here are large Maori owned } \\
\text { blocks, and when I talk to the other } \\
\text { managers, they've pretty much } \\
\text { found the same thing. There's a } \\
\text { couple on lower benchmarks that } \\
\text { sort of get a little bit - the farms } \\
\text { were probably not as developed, so } \\
\text { that's probably limited how much } \\
\text { they can develop their farms. But in } \\
\text { general, I don't think it has affected } \\
\text { things too much." }\end{array}$ \\
\hline \multicolumn{3}{|l|}{ WO_neutral social } \\
\hline WO_Neu_acceptance & & $\begin{array}{l}\text { "But, you know, it's something that } \\
\text { I've been involved with for } 30 \text { years } \\
\text { of farming and so it's been a major } \\
\text { cost to farms definitely, which } \\
\text { everybody seems to have just - just } \\
\text { get on with it." }\end{array}$ \\
\hline WO_Neu_well-being & & $\begin{array}{l}\text { "Socially, some people who are } \\
\text { really unhappy have gone. Which is } \\
\text { good they've sold, probably still not } \\
\text { happy but they were able to exit. } \\
\text { Some of the angst around that was } \\
\text { that the trust stood on the market } \\
\text { and paid what private valuations, } \\
\text { but some of those people still say } \\
\text { that wasn't enough." }\end{array}$ \\
\hline WO_Neu_fairness & Policy is both fair and unfair & $\begin{array}{l}\text { "Everybody's got to do their share. } \\
\text { Are they picking on us? No, I don't } \\
\text { think so. Some people think they } \\
\text { are, but I think everyone's gotta do } \\
\text { their part. I think there's certainly } \\
\text { been room for improvement; I think } \\
\text { it runs you know. I only see } \\
\text { something no one's - nothing's } \\
\text { gonna change." }\end{array}$ \\
\hline \multicolumn{3}{|l|}{ WO_positive ecological } \\
\hline $\begin{array}{l}\text { WO_Pos_land use } \\
\text { patterns }\end{array}$ & & $\begin{array}{l}\text { "I think there would be a lot more } \\
\text { dairy farms [without the policy], } \\
\text { particularly on Maori lands down } \\
\text { the bottom of the lake, which is just } \\
\text { beautiful land. There would have } \\
\text { been more development, yep. So, it } \\
\text { met its purpose. I think the lake is } \\
\text { improving too." }\end{array}$ \\
\hline $\begin{array}{l}\text { WO_Pos_management } \\
\text { changes }\end{array}$ & & $\begin{array}{l}\text { "I see the bigger farms - a lot of } \\
\text { them are doing cover crops where } \\
\text { they never did before." }\end{array}$ \\
\hline
\end{tabular}




\begin{tabular}{|c|c|c|}
\hline WO_Pos_water quality & & $\begin{array}{l}\text { "So - so, yeah, so, - but we want the } \\
\text { lake to get - to get better as well } \\
\text { and we-we-we think we're seeing } \\
\text { that so there's a-we - we do think } \\
\text { there is a balance in things, but - } \\
\text { but then the financial imperative } \\
\text { sort of seasonal; these are making } \\
\text { some good decisions anyway, } \\
\text { unfortunately." }\end{array}$ \\
\hline \multicolumn{3}{|l|}{ WO_positive economic } \\
\hline $\begin{array}{l}\text { WO_Pos_farming } \\
\text { viability }\end{array}$ & & $\begin{array}{l}\text { "And that is one of the best thing } \\
\text { that has actually happened in this } \\
\text { catchment, is that we have, we can } \\
\text { trade effectively. So it doesn't lock } \\
\text { someone in forever and gives people } \\
\text { flexibility and things like that. A lot } \\
\text { of people wouldn't actually realize } \\
\text { that or use that or whatever, but } \\
\text { that is huge flexibility. You've got to } \\
\text { have that flexibility if you want to go } \\
\text { ahead." }\end{array}$ \\
\hline WO_Pos_financial & $\begin{array}{l}\text { profit, payoff, funding, } \\
\text { reduced earnings, compliance, } \\
\text { property value, new revenue } \\
\text { streams including new } \\
\text { products, new markets, } \\
\text { diversification }\end{array}$ & $\begin{array}{l}\text { "So for the Maori incorporations the } \\
\text { benefits were huge. They could take } \\
\text { capital out of land but they can't sell } \\
\text { it. So Maori land can't be sold. So if } \\
\text { it was me, I owned this land and I } \\
\text { couldn't sell it and someone was } \\
\text { going to give me a whole lot of } \\
\text { money for that land and I owned it, } \\
\text { I'd have planted the whole thing in } \\
\text { trees...So it allowed them to release } \\
\text { capital out of their land holdings, } \\
\text { retain their land because they can't } \\
\text { sell it and then they've taken that } \\
\text { money out and my incorporation } \\
\text { have treated it as capital." }\end{array}$ \\
\hline \multicolumn{3}{|l|}{ WO_positive social } \\
\hline WO_Pos_awareness & $\begin{array}{l}\text { awareness of water quality, } \\
\text { farm dynamics and } \\
\text { environmental footprint }\end{array}$ & $\begin{array}{l}\text { "Well, farmers have become aware } \\
\text { of the environmental impacts that } \\
\text { farming has on the waterways and } \\
\text { the lakes." }\end{array}$ \\
\hline WO_Pos_well-being & $\begin{array}{l}\text { community involvement, } \\
\text { depression, community } \\
\text { members leaving }\end{array}$ & $\begin{array}{l}\text { "So, yeah. Actually, I think that } \\
\text { probably the biggest plus out of it is } \\
\text { actually talking to your neighbor, } \\
\text { and working with your neighbor, } \\
\text { and seeing what they're doing." }\end{array}$ \\
\hline WO_Pos_fairness & $\begin{array}{l}\text { perceived fairness of the } \\
\text { policy process/policy } \\
\text { outcomes }\end{array}$ & $\begin{array}{l}\text { "Yes, I do, absolutely. I think we } \\
\text { have a workable proposition, a } \\
\text { workable nitrogen constraint." }\end{array}$ \\
\hline \multicolumn{3}{|l|}{$\begin{array}{l}\text { Recent nutrient } \\
\text { management behavior }\end{array}$} \\
\hline Management change & & \\
\hline
\end{tabular}




\begin{tabular}{|c|c|c|}
\hline M_change breed & $\begin{array}{l}\text { Change in animal stock, part } \\
\text { of the physical stock of the } \\
\text { farm, not something that can } \\
\text { be changed on a day to day } \\
\text { management basis. }\end{array}$ & $\begin{array}{l}\text { "Basically, change the breed really. } \\
\text { As I say, they were very high } \\
\text { maintenance. We had dry seasons } \\
\text { and the following year they didn't } \\
\text { perform very well. So we got a } \\
\text { hardier, bit more robust sheep on } \\
\text { board, but they don't produce quite } \\
\text { as much, but they cost - the cost of } \\
\text { running them has dropped as well, } \\
\text { so - and that was to fit with putting } \\
\text { milking on it, sort of changed the } \\
\text { dynamics of the farm, so just that fit } \\
\text { with the whole system." }\end{array}$ \\
\hline M_reduced fertilizer & $\begin{array}{l}\text { changes in the application of } \\
\text { fertilizer timing and/or } \\
\text { amount, including manure }\end{array}$ & $\begin{array}{l}\text { "Just, I suppose, I have changed } \\
\text { from putting the fertilizer on in the } \\
\text { autumn to putting it on in the } \\
\text { spring. Or late spring, probably, } \\
\text { more than early spring. Due to, } \\
\text { probably, a bigger loss would occur } \\
\text { in the autumn." }\end{array}$ \\
\hline M_grazing off & $\begin{array}{l}\text { Began or changed grazing off } \\
\text { of livestock, or wintering off, } \\
\text { including dairy support }\end{array}$ & $\begin{array}{l}\text { "What we've done instead of winter } \\
\text { cropping and wintering on the farm, } \\
\text { we've taken more animals off the } \\
\text { farm during the winter. It also } \\
\text { helped that the grasses that were } \\
\text { growing now provide feed over a } \\
\text { wider part of the season. But it's } \\
\text { both continual productivity } \\
\text { improvements that has come to help } \\
\text { in the situation." }\end{array}$ \\
\hline M_increased fertilizer & $\begin{array}{l}\text { increase in the application of } \\
\text { fertilizer }\end{array}$ & $\begin{array}{l}\text { "And then, in the last few years, } \\
\text { we've found that we haven't really } \\
\text { had enough manure on the closer } \\
\text { fields, and it costs a lot more to get } \\
\text { it to the further fields, so the last } \\
\text { few years, we've been putting more } \\
\text { commercial fertilizer on the further } \\
\text { fields, and sometimes no manure, } \\
\text { and putting more of that manure on } \\
\text { the grass ground during the summer } \\
\text { and definitely putting more -or, } \\
\text { enough - on the corn ground that's } \\
\text { close by." }\end{array}$ \\
\hline $\begin{array}{l}\text { M_increased stocking } \\
\text { rate }\end{array}$ & & $\begin{array}{l}\text { "Yeah, chicken as well, so it's kind of } \\
\text { a quick background. I guess I'd say } \\
\text { also we've grown the flock a little bit } \\
\text {-" }\end{array}$ \\
\hline M_pursue knowledge & $\begin{array}{l}\text { Actively pursue knowledge to } \\
\text { better understand nutrient } \\
\text { dynamics (engage in research) }\end{array}$ & $\begin{array}{l}\text { "We've actively pursued knowledge } \\
\text { by engaging in research trials." }\end{array}$ \\
\hline
\end{tabular}




\begin{tabular}{|c|c|c|}
\hline M_manure spreading & $\begin{array}{l}\text { Changes in the application of } \\
\text { manure timing, amount or } \\
\text { pattern, also changes in } \\
\text { location of manure stacking }\end{array}$ & $\begin{array}{l}\text { "I bought a manure truck, so I had to } \\
\text { do it myself, now. I'm gonna do - } \\
\text { rather than hiring somebody to } \\
\text { come in and mainly want the pit } \\
\text { empty, so just put it on as heavy as } \\
\text { they can put it on because they're } \\
\text { only coming in once or twice a year. } \\
\text { Well, doing it myself, I'll do it more } \\
\text { times per year, less each time, and } \\
\text { try to minimalize runoff and get on } \\
\text { when the land needs it. When the } \\
\text { land can use it. That way, } \\
\text { absorption is better and l'd like to } \\
\text { hit it as soon after cropping and } \\
\text { pray for doing it the day before a } \\
\text { rain, that way it gets incorporated } \\
\text { in." }\end{array}$ \\
\hline M_notill & Switch to no-till & $\begin{array}{l}\text { "Then, as for fields, the last few } \\
\text { years we've been - we've been kind } \\
\text { of experimenting with no till for } \\
\text { about } 20 \text { years, and probably six or } \\
\text { seven years ago we went halfway no } \\
\text { till and four years we got to } 100 \\
\text { percent no till -" }\end{array}$ \\
\hline $\begin{array}{l}\text { M_nutrient } \\
\text { management plan }\end{array}$ & $\begin{array}{l}\text { Began or revised a nutrient } \\
\text { management plan or overseer } \\
\text { plan }\end{array}$ & $\begin{array}{l}\text { "That was my first effort at writing } \\
\text { my NMP, yeah. We had a different } \\
\text { contractor doing it for us initially the } \\
\text { first year or two. Even back then, we } \\
\text { were already at } \$ 4,500.00 \text {, } \\
\$ 5,000.00 \text { then and we didn't have } \\
\text { the land base that we have now." }\end{array}$ \\
\hline M_reduce feed inputs & $\begin{array}{l}\text { Changes in purchased feed or } \\
\text { other inputs (non-fertilizer) }\end{array}$ & $\begin{array}{l}\text { "Yeah we also bring in palm kernel } \\
\text { at this stage. Yeah we have cut } \\
\text { down - well we're trying to do at the } \\
\text { moment because it is not worth } \\
\text { losing money on using it." }\end{array}$ \\
\hline M_seeding or cropping & $\begin{array}{l}\text { Began, changed or stopped } \\
\text { seeding varieties or cropping } \\
\text { patterns }\end{array}$ & $\begin{array}{l}\text { "Yeah, yeah. We're gonna seed } \\
\text { more, now. We always like our corn } \\
\text { but we used to plant } 300 \text { acres and } \\
\text { now we're down to } 180 . "\end{array}$ \\
\hline M_soil sampling & $\begin{array}{l}\text { Began or changed soil } \\
\text { sampling }\end{array}$ & $\begin{array}{l}\text { "Talking with USDA, I'm trying to } \\
\text { reseed to improve my pastures and } \\
\text { so l'Il be doing some soil testing. I } \\
\text { didn't do that when I went to the } \\
\text { [nutrient management class], but I } \\
\text { will now just so that I better } \\
\text { understand." }\end{array}$ \\
\hline M_stocking rate & $\begin{array}{l}\text { Changed number of animal } \\
\text { units }\end{array}$ & $\begin{array}{l}\text { "No, there's no reduction in - well, } \\
\text { actually it did come with a reduction } \\
\text { in stocking rate as well. I think I've } \\
\text { mentioned that we reduced from } \\
\text { about 3.4 down to 2.9." }\end{array}$ \\
\hline
\end{tabular}




\begin{tabular}{|c|c|c|}
\hline Structural change & & \\
\hline St_barn & Change or construct barns & $\begin{array}{l}\text { "Then we're actually building a barn } \\
\text { to bring these animals home } \\
\text { because that contract grade is - } \\
\text { they're doing a nice job raising } \\
\text { them, but that's - we can more than } \\
\text { pay for a barn." }\end{array}$ \\
\hline St_biodigester & & $\begin{array}{l}\text { "[Q: When did you guys put in the } \\
\text { biodigester?] 2008... Yup. It was } \\
\text { something we decided to do." }\end{array}$ \\
\hline St_buffers & $\begin{array}{l}\text { Change or construct buffers or } \\
\text { setbacks on rivers, streams or } \\
\text { ditches }\end{array}$ & $\begin{array}{l}\text { "right, yeah, and some ditches and } \\
\text { with buffers I think was the last } \\
\text { project we did a while back was } \\
\text { maybe } 30 \text { feet and then they came } \\
\text { and planted trees and they help } \\
\text { even compensate us a small amount } \\
\text { for the land that we lost because our } \\
\text { fields did go right down to those } \\
\text { areas." }\end{array}$ \\
\hline St_detainment bunds & $\begin{array}{l}\text { Change or build detainment } \\
\text { berms to control flow of } \\
\text { water, slow flow of water and } \\
\text { runoff of nutrients }\end{array}$ & $\begin{array}{l}\text { "Obviously where we pug ground up } \\
\text { is another issue, we are always } \\
\text { conscious of that, but we've also put } \\
\text { in a lot of detainment berms, if you } \\
\text { can imagine this farm is elevated it's } \\
\text { got quite a big catchment and all } \\
\text { the water eventually is coming down } \\
\text { into the lake. It's going to get there } \\
\text { one way or the other. These } \\
\text { detainment berms, so far we have } \\
\text { done about seven with the regional } \\
\text { Council to reduce or to mitigate the } \\
\text { flow of water that comes through, } \\
\text { especially when we have these big } \\
\text { downpours." }\end{array}$ \\
\hline St_equipment & $\begin{array}{l}\text { Purchase or change farming } \\
\text { equipment }\end{array}$ & $\begin{array}{l}\text { "We have adopted the best } \\
\text { management practice advice in } \\
\text { terms of effluent and disposal. We } \\
\text { put in a new storage system. A } \\
\text { rubber-lined storage system. It - to } \\
\text { have best practice for effluent and } \\
\text { disposal. We brought new land } \\
\text { application irrigators to meet the } \\
\text { application requirement." }\end{array}$ \\
\hline St_fencing & Change or construct fences & $\begin{array}{l}\text { "We had to fence up the swamps } \\
\text { because there are some wetlands on } \\
\text { the backside of a couple of our fields } \\
\text { that we had to fence out. Water } \\
\text { quality. Like I said, it all makes } \\
\text { sense. It makes you more money in } \\
\text { the long run. Cows aren't gonna } \\
\text { make milk standing in the mud." }\end{array}$ \\
\hline
\end{tabular}




\begin{tabular}{|c|c|c|}
\hline St_leachate system & & $\begin{array}{l}\text { "The biggest problem I have is we } \\
\text { have to put a leachate system in. } \\
\text { Ugh. It's an } \$ 81,000.00 \text { project, } \\
\text { which I don't think is even needed } \\
\text { because our bunker are - well, } \\
\text { they're } 100 \text { feet from the brook and } \\
\text { they're } 50 \text { feet from the road." }\end{array}$ \\
\hline St_manure pit or pad & $\begin{array}{l}\text { Change or construct manure } \\
\text { pit }\end{array}$ & $\begin{array}{l}\text { "By getting manure on the land -we } \\
\text { put in a manure pit - by getting the } \\
\text { manure on the land, we went - our } \\
\text { tonnage of feed multiplied by four } \\
\text { times in two years, per acre. It's } \\
\text { huge. That's all money in your } \\
\text { pocket because you're not } \\
\text { purchasing that extra feed." }\end{array}$ \\
\hline St_milking parlor & $\begin{array}{l}\text { change or construct milking } \\
\text { parlor }\end{array}$ & $\begin{array}{l}\text { "We've been going about eight or } \\
\text { nine years. Eight years, yeah. It } \\
\text { didn't actually take that long, built a } \\
\text { shed, a purpose built milking shed } \\
\text { and pretty much within } 12 \text { months } \\
\text { we were producing milk." }\end{array}$ \\
\hline St_stand-off pad & $\begin{array}{l}\text { Change or construct stand-off } \\
\text { pad }\end{array}$ & $\begin{array}{l}\text { "We still have no - on our own, we } \\
\text { put in a cement pad to feed the } \\
\text { cows on. We're still dealing with- } \\
\text { we kind of get a nice bedded pack } \\
\text { built that's dry, and then we get six } \\
\text { inches of snow on top of it-" }\end{array}$ \\
\hline St_tree planting & $\begin{array}{l}\text { Plant trees to restore banks or } \\
\text { native bush (not pine } \\
\text { plantation - that is a system } \\
\text { change) }\end{array}$ & $\begin{array}{l}\text { "Apart from fencing off gullies and } \\
\text { planting them in natives, rather } \\
\text { than productions trees, that's about } \\
\text { it." }\end{array}$ \\
\hline $\begin{array}{l}\text { St_water flow control } \\
\text { structures }\end{array}$ & $\begin{array}{l}\text { add or change culvert, put in } \\
\text { drains to divert water }\end{array}$ & $\begin{array}{l}\text { "Some of our diversion water goes } \\
\text { through a culvert underneath this } \\
\text { pushway. I didn't wanna pour } \\
\text { concrete there, so what I did is I } \\
\text { added onto the culvert on both sides } \\
\text { and just built it up, so now the dirt is } \\
\text { much higher than our concrete } \\
\text { pushway, and when she came back, } \\
\text { she said that was fine." }\end{array}$ \\
\hline \multicolumn{3}{|l|}{ System change } \\
\hline $\begin{array}{l}\text { Sy_purchase or lease } \\
\text { land }\end{array}$ & $\begin{array}{l}\text { Purchase new land for } \\
\text { agriculture within the policy } \\
\text { region }\end{array}$ & $\begin{array}{l}\text { "Well, we just barely purchased } \\
\text { some more land. We're up to } 280 \\
\text { acres. We rent another } 100 \text { acres of } \\
\text { crop land." }\end{array}$ \\
\hline
\end{tabular}




\begin{tabular}{|c|c|c|}
\hline $\begin{array}{l}\text { Sy_put land in } \\
\text { production }\end{array}$ & & $\begin{array}{l}\text { "Then there was a white pine stand } \\
\text { that we wanted to cut and reclaim } \\
\text { for pasture and we wanted to clear } \\
\text { all that junk wood, and then we } \\
\text { wanted to drastically thin out the } \\
\text { hemlock out of the sugar } \\
\text { bush... "Yep, he gave me approval." I } \\
\text { said "Can we start?" "Yeah, go } \\
\text { ahead. Get started." We start. Clear } \\
\text { cut } 20 \text { acres here, and clear cut a } \\
\text { bunch here, and do a bunch of work, } \\
\text { and we only did, probably } 25 \\
\text { percent of what we wanted to do -" }\end{array}$ \\
\hline Sy_sale or lease of land & Sale of agricultural land & $\begin{array}{l}\text { "So we decided after a lot of soul- } \\
\text { searching that we would sell." }\end{array}$ \\
\hline $\begin{array}{l}\text { Sy_switch to higher } \\
\text { intensity }\end{array}$ & $\begin{array}{l}\text { Transition to or from dairy, } \\
\text { sheep, beef, vegetable, other, } \\
\text { pine plantation, dairy support. } \\
\text { Note that many farms can be } \\
\text { multiple different farm } \\
\text { systems at once, and may take } \\
\text { up additional system types, } \\
\text { for example a dairy may retire } \\
\text { some land and plant a pine } \\
\text { plantation. Switch from } \\
\text { breeding operation to } \\
\text { purchasing stock included as } \\
\text { well, or reverse, switch from } \\
\text { purchasing to breeding }\end{array}$ & $\begin{array}{l}\text { "Well, one would be put the sheep } \\
\text { milking unit on...So basically, we've } \\
\text { put that on and it has changed the } \\
\text { dynamics a little bit. And then we've } \\
\text { sort of intensified that area, the } \\
\text { sheep milking area, quite a bit. } \\
\text { Mainly with the sheep, but it hasn't } \\
\text { changed our nutrient output a hell } \\
\text { of a lot, I don't think." }\end{array}$ \\
\hline $\begin{array}{l}\text { Sy_switch to lower } \\
\text { intensity }\end{array}$ & $\begin{array}{l}\text { Transition to or from dairy, } \\
\text { sheep, beef, vegetable, other, } \\
\text { pine plantation, dairy support. } \\
\text { Note that many farms can be } \\
\text { multiple different farm } \\
\text { systems at once, and may take } \\
\text { up additional system types, } \\
\text { for example a dairy may retire } \\
\text { some land and plant a pine } \\
\text { plantation. Switch from } \\
\text { breeding operation to } \\
\text { purchasing stock included as } \\
\text { well, or reverse, switch from } \\
\text { purchasing to breeding }\end{array}$ & $\begin{array}{l}\text { "Really, since we went grass fed- } \\
\text { this is recent - we've had to - we're } \\
\text { still trying to figure out how this is } \\
\text { changing our - last summer was the } \\
\text { first summer we were } 100 \text { percent } \\
\text { grass fed." }\end{array}$ \\
\hline
\end{tabular}




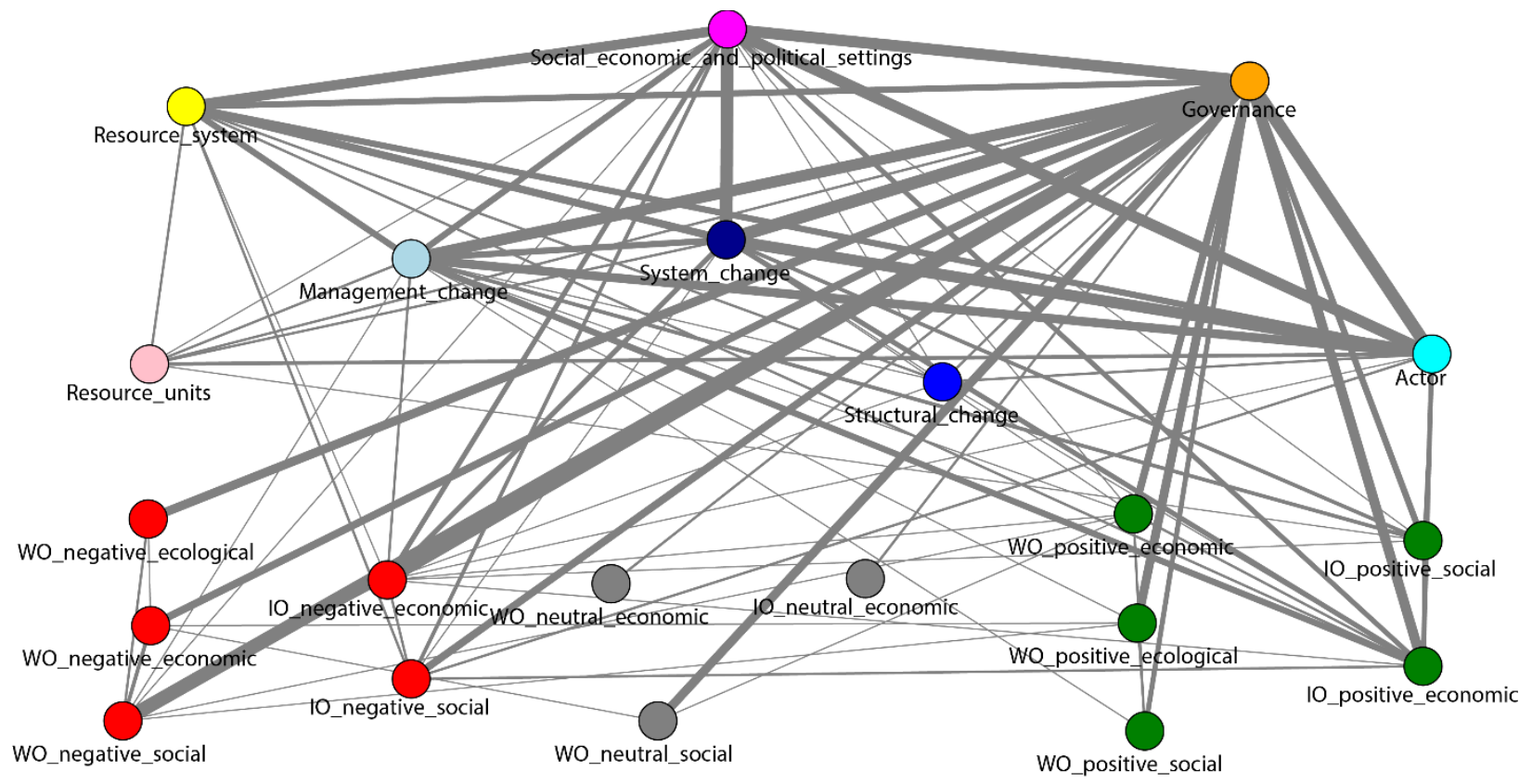

Figure A1.1. Network graph representing group mental model of Taupo farmers' watershed socialecological system. The arrangement of nodes mimics the structure of the SES Framework in Error! Reference source not found. above. Color of node represents the category of node: driver nodes are orange (governance), magenta (social, economic and political settings), yellow (resource system), cyan (actor), and pink (resource system); behavior nodes are light blue (management), blue (structural) and navy (system); watershed (WO) and individual (IO) outcomes nodes are red (negative), grey (neutral) and green (positive).

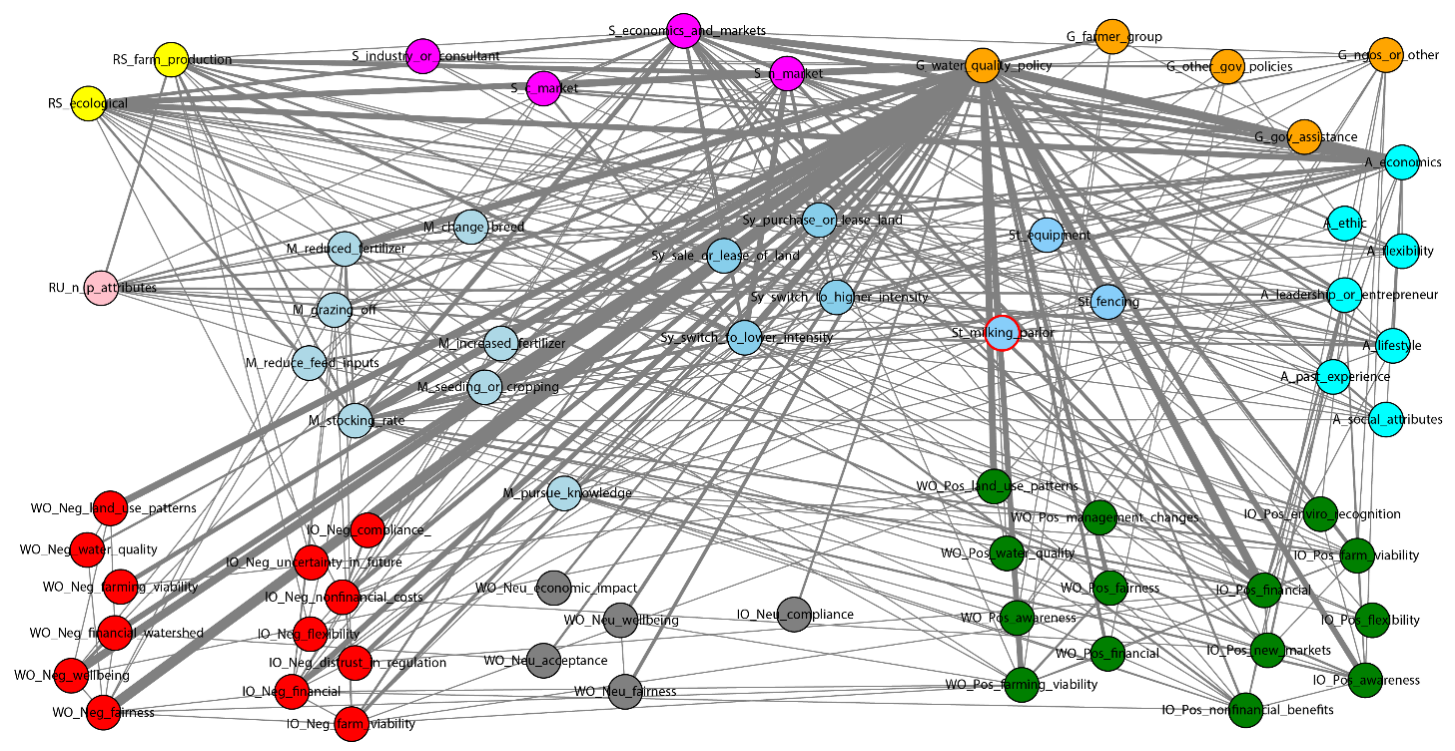

Figure A1.2. Taupo SES sub-category group mental model network. 


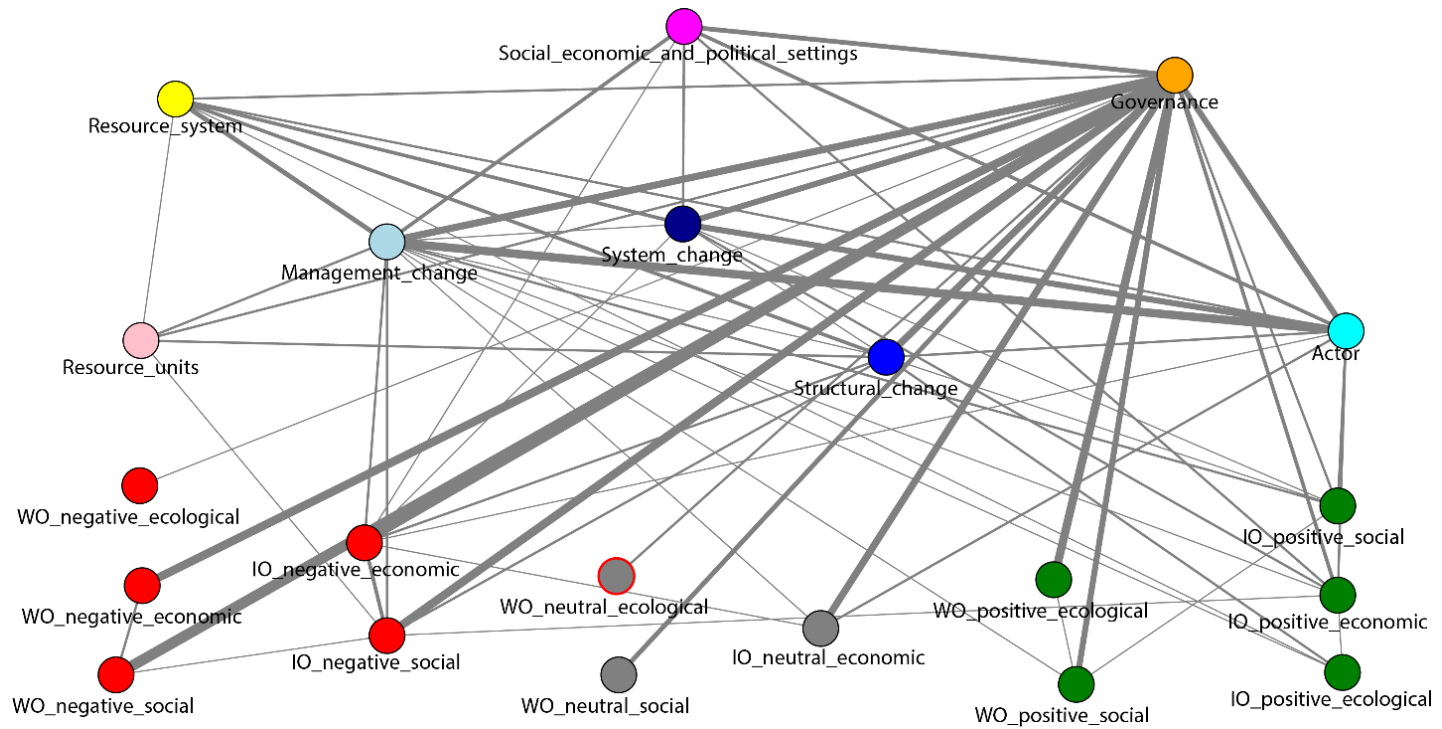

Figure A1.3. Rotorua SES Category group mental model network

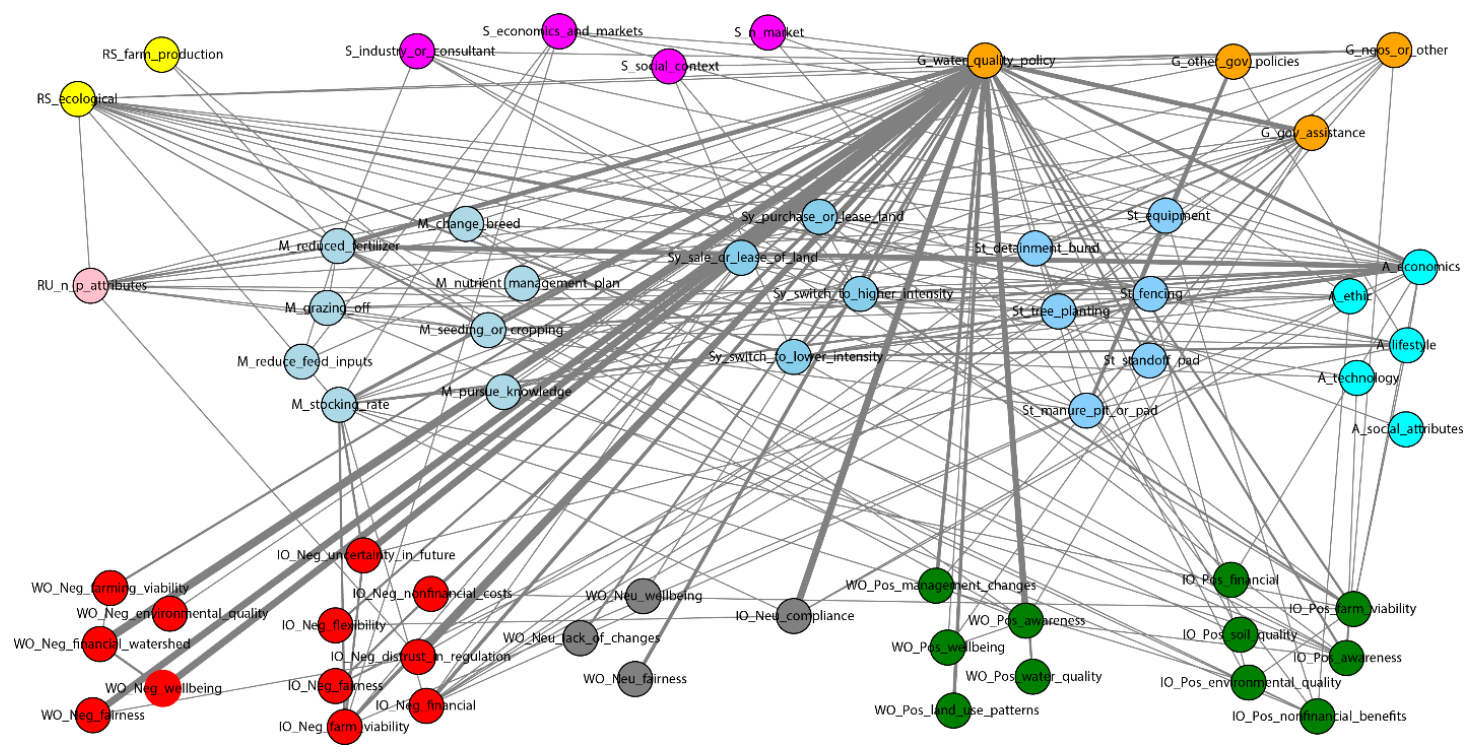

Figure A1.4. Rotorua SES sub-category group mental model network 


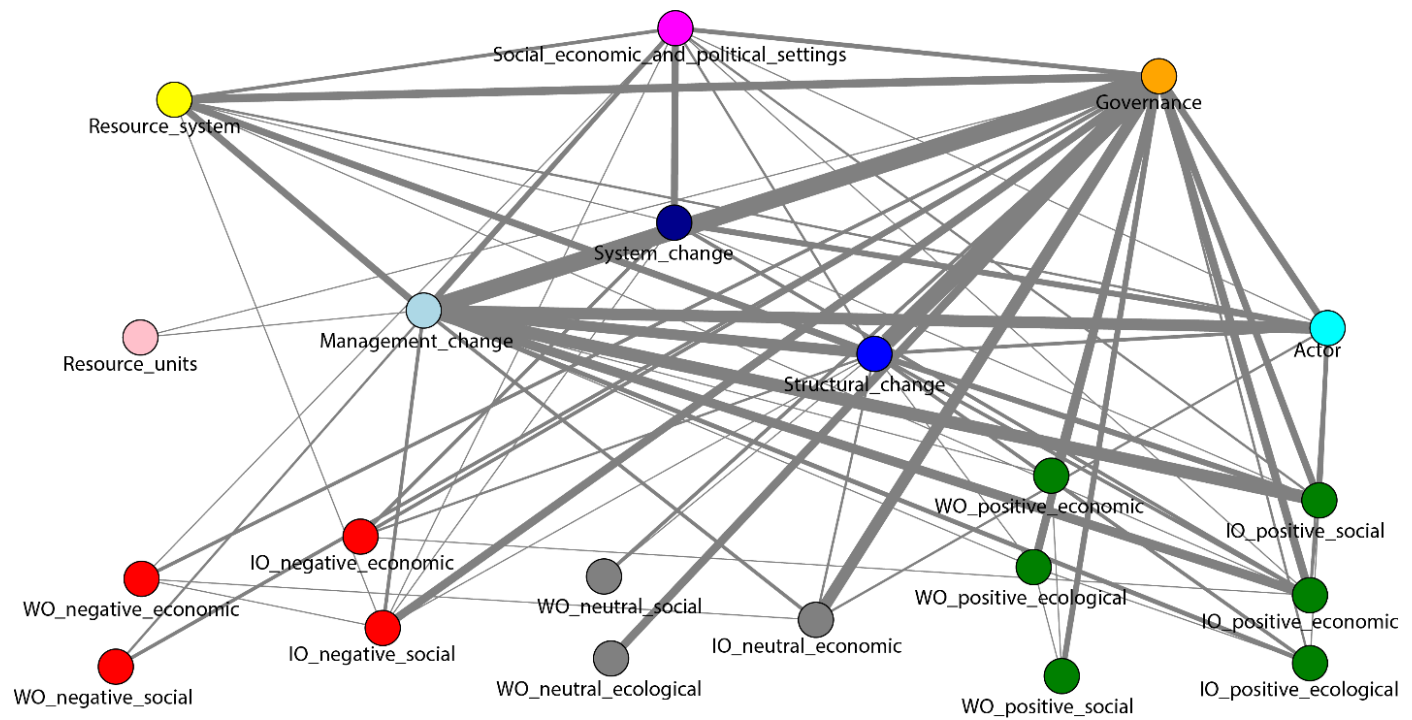

Figure A1.5. Vermont SES Category group mental model network

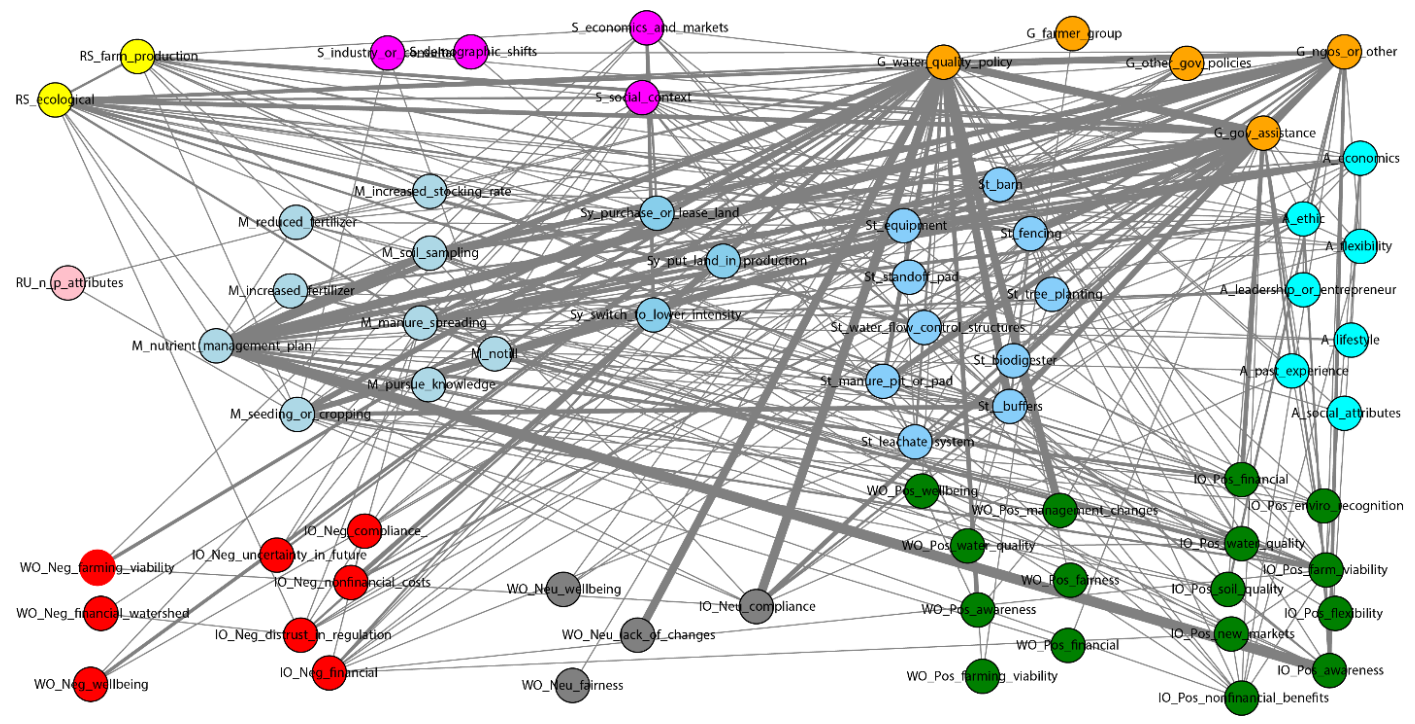

Figure A1.6. Vermont SES sub-category group mental model network. 
Table A1.3. Driver node statistics by region in Driver-behavior sub-network. Rank reflects the descending rank of strength (high to low). The data driving these ranks is from the Driver-behavior sub-network so ranks do not reflect influence on outcomes.

\begin{tabular}{|c|c|c|c|c|c|c|c|c|c|c|c|c|}
\hline \multirow[b]{2}{*}{ Sub-category node } & \multicolumn{4}{|c|}{ Taupo $(n=11)$} & \multicolumn{4}{|c|}{ Vermont $(n=16)$} & \multicolumn{4}{|c|}{ Rotorua $(n=11)$} \\
\hline & rank & strength & degree & $\begin{array}{l}\text { occurrence } \\
\text { probability }\end{array}$ & rank & strength & degree & $\begin{array}{l}\text { occurrence } \\
\text { probability }\end{array}$ & rank & strength & degree & $\begin{array}{l}\text { occurrence } \\
\text { probability }\end{array}$ \\
\hline A_economics & 2 & 49 & 23 & $91 \%$ & 5 & 21 & 13 & $50 \%$ & 2 & 25 & 16 & $64 \%$ \\
\hline A_ethic & 14 & 2 & 2 & $9 \%$ & 6 & 17 & 15 & $38 \%$ & 8 & 5 & 5 & $18 \%$ \\
\hline A_flexibility & 10 & 9 & 7 & $18 \%$ & 9 & 8 & 8 & $13 \%$ & - & - & - & - \\
\hline $\begin{array}{l}\text { A_leadership_or } \\
\text { _entrepreneur }\end{array}$ & 7 & 17 & 12 & $27 \%$ & 10 & 4 & 3 & $13 \%$ & - & - & - & - \\
\hline A_lifestyle & 8 & 16 & 11 & $27 \%$ & 11 & 3 & 3 & $6 \%$ & 6 & 9 & 8 & $36 \%$ \\
\hline A_past_experience & 12 & 5 & 5 & $9 \%$ & 10 & 4 & 3 & $13 \%$ & - & - & - & - \\
\hline A_social_attributes & 10 & 9 & 8 & $27 \%$ & 12 & 2 & 2 & $6 \%$ & 11 & 1 & 1 & $9 \%$ \\
\hline A_technology & - & - & - & - & - & - & - & - & 10 & 2 & 2 & $9 \%$ \\
\hline G_farmer_group & 12 & 5 & 3 & $27 \%$ & 13 & 1 & 1 & $6 \%$ & - & - & - & - \\
\hline G_gov_assistance & 10 & 9 & 7 & $18 \%$ & 1 & 74 & 25 & $88 \%$ & 4 & 14 & 9 & $45 \%$ \\
\hline G_ngos_or_other & 11 & 7 & 7 & $9 \%$ & 3 & 48 & 22 & $75 \%$ & 6 & 9 & 8 & $36 \%$ \\
\hline G_other_gov_policies & 13 & 4 & 3 & $27 \%$ & 10 & 4 & 4 & $13 \%$ & 7 & 8 & 5 & $27 \%$ \\
\hline G_water_quality_policy & 1 & 88 & 28 & $100 \%$ & 2 & 58 & 26 & $94 \%$ & 1 & 42 & 25 & $100 \%$ \\
\hline RS_ecological & 5 & 31 & 18 & $45 \%$ & 4 & 31 & 18 & $44 \%$ & 3 & 17 & 15 & $55 \%$ \\
\hline RS_farm_production & 6 & 23 & 14 & $64 \%$ & 6 & 17 & 13 & $31 \%$ & 10 & 2 & 2 & $9 \%$ \\
\hline RU_n_p_attributes & 8 & 16 & 11 & $27 \%$ & 12 & 2 & 2 & $6 \%$ & 5 & 11 & 10 & $27 \%$ \\
\hline S_c_market & 9 & 11 & 7 & $18 \%$ & - & - & - & - & - & - & - & - \\
\hline S_demographic_shifts & - & - & - & - & 13 & 1 & 1 & $6 \%$ & - & - & - & - \\
\hline $\begin{array}{l}\text { S_economics_and } \\
\text { _markets }\end{array}$ & 4 & 40 & 18 & $82 \%$ & 8 & 9 & 6 & $44 \%$ & 8 & 5 & 5 & $9 \%$ \\
\hline $\begin{array}{l}\text { S_industry_or } \\
\text { _consultant }\end{array}$ & 13 & 4 & 4 & $9 \%$ & 10 & 4 & 4 & $6 \%$ & 8 & 5 & 5 & $18 \%$ \\
\hline S_n_market & 3 & 42 & 18 & $82 \%$ & - & - & - & - & 10 & 2 & 2 & $9 \%$ \\
\hline S_social_context & - & - & - & - & 7 & 15 & 13 & $19 \%$ & 9 & 3 & 3 & $9 \%$ \\
\hline
\end{tabular}

Note: The one letter prefix of the driver sub-category node name represents the overall driver category that the node belongs to: $A=A c t o r, G=$ Governance, RS $=$ Resource System, RU $=$ Resource Units, $S=$ Social, economic and political setting. 
Table A1.4. Drivers ranked by strength across each region. Note that data driving these ranks is from the Driverbehavior sub-network so ranks do not reflect influence on outcomes. The one letter prefix of the driver subcategory node name represents the overall driver category that the node belongs to.

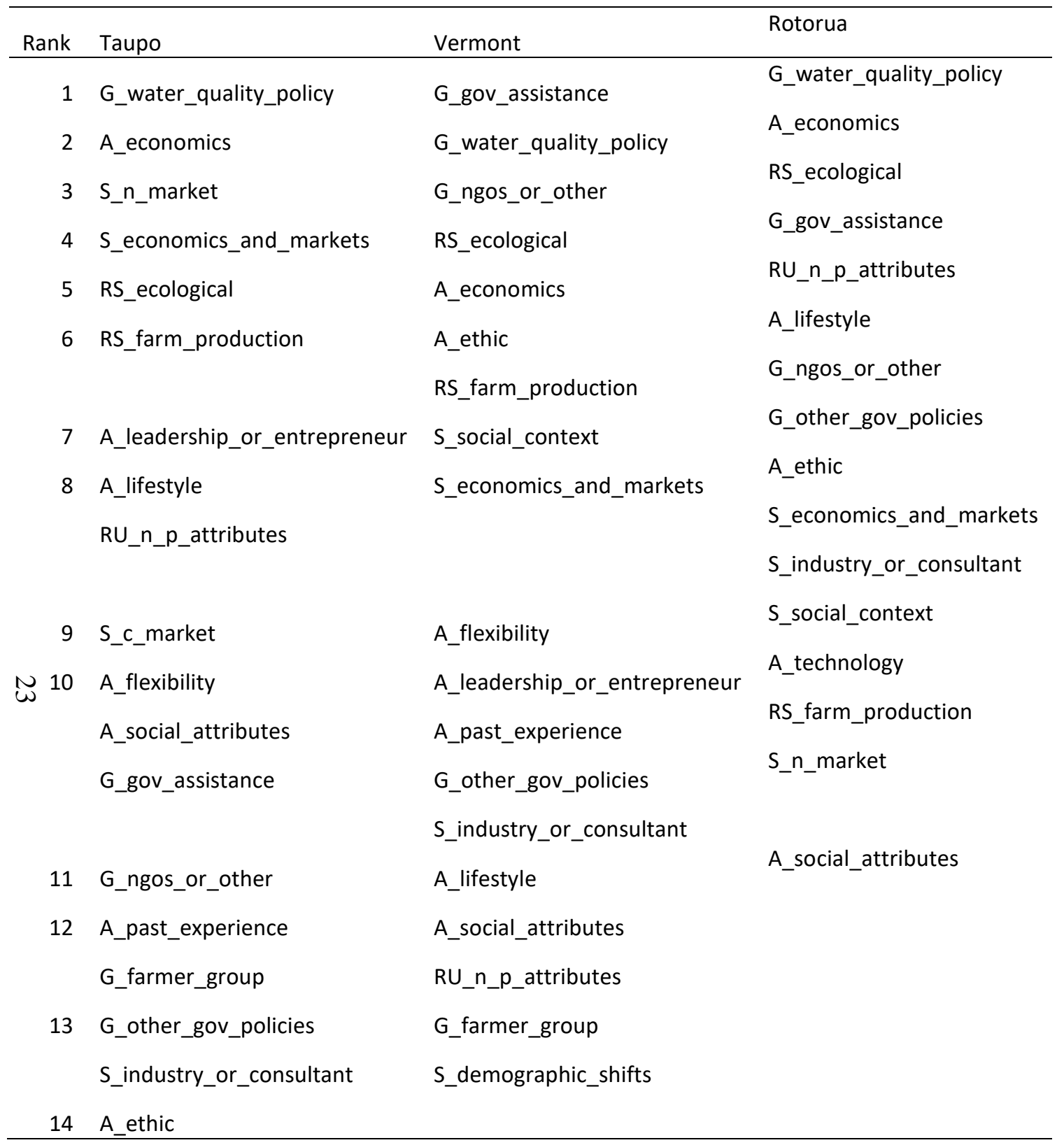

